\title{
BORROW LESS TOMORROW: BEHAVIORAL APPROACHES TO DEBT REDUCTION
}

\author{
Dean Karlan and Jonathan Zinman
}

\author{
Hovey House \\ 140 Commonwealth Avenue \\ Chestnut Hill, MA 02467 \\ Tel: 617-552-1762 \\ http://fsp.bc.edu
}

Dean Karlan is president, founder, and executive director of Innovations for Poverty Action (IPA) and a professor of economics at Yale University. Jonathan Zinman is a research affiliate of IPA and an associate professor of economics at Dartmouth College. The research reported here was performed pursuant to a grant from the U.S. Social Security Administration (SSA) funded as part of the Financial Literacy Research Consortium (FLRC) and FINRA Investor Education Foundation. The opinions and conclusion expressed are solely those of the authors and do not represent the opinions or policy of SSA, any agency of the federal government, the FLRC, FINRA Investor Education Foundation, IPA, Yale University, Dartmouth College, or Boston College. The authors are indebted to Shlomo Benartzi and Dick Thaler for helpful discussions and their pioneering work on Save More Tomorrow ${ }^{\mathrm{TM}}$. The authors would like to thank David Matsa and conference participants in the NBER Law and Economics Group for helpful comments. They would also like to thank Brooke Berman, Selvan Kumar, Becca Lowry, Gautam Nair, Rebecca Rouse, and other IPA staffers for research support and fieldwork. Finally, they would like to thank the leaders and staff at the Community Action Project of Tulsa County in Tulsa, Oklahoma for helping develop and pilot-test Borrow Less Tomorrow.

(C) 2012, by Dean Karlan and Jonathan Zinman. All rights reserved. Short sections of text, not to exceed two paragraphs, may be quoted without explicit permission provided that full credit, including (C) notice, is given to the source. 


\begin{abstract}
Mounting evidence suggests that behavioral factors depress wealth accumulation. Although much research and policy focuses on asset accumulation, for many households debt decumulation is more efficient. Yet the mass market for debt reduction services is thin. So we develop and pilot test Borrow Less Tomorrow (BoLT), a behavioral approach to debt reduction that combines a simple decision aid, social commitment, and reminders. Results from a sample of free tax-preparation clients with eligible debt in Tulsa ( $\mathrm{N}=465)$ indicate strong demand for debt reduction: $41 \%$ of those offered BoLT used it to make a plan to accelerate debt repayment. Using random assignment to BoLT offers, we find weak evidence that the BoLT package offered reduces credit card debt.
\end{abstract}




\section{Introduction}

Mounting evidence suggests that behavioral biases and cognitive limitations (which we referred to loosely as "behavioral factors”) depress wealth accumulation. ${ }^{1}$ Most applications of this research have focused on asset accumulation: using behavioral insights to develop product and policy innovations, thus far largely delivered through U.S. workplaces, that facilitate increased saving or investment for retirement. $^{2}$ There is also mounting evidence that behavioral factors may lead households to "over borrow” as well as "under save," 3 but little of this work has developed or tested potential solutions. This is not for wont of need. For many households debt decumulation is a more efficient route to increase net worth; e.g., many more households hold debt than financial assets, and historical credit card and auto loan interest rates exceed historical equity returns. But the mass market for debt reduction advice and products is thin. ${ }^{4}$

This opportunity motivates us to develop and test Borrow Less Tomorrow (BoLT), a behavioral approach to debt reduction that combines a simple planning/goal-setting process, commitment, and reminders. The planning/goal-setting process in the present study involved interested clients working with a surveyor/marketer to identify a suitable auto loan or credit card and come up with a realistic repayment schedule that would accelerate repayment. Marketers worked with the client to identify a relatively high-APR debt and used a simple spreadsheet to help illustrate the impact of different monthly payment amounts on total repayment time and interest paid. The voluntary commitment option here was social in nature: a BoLT client could name one or more peer supporters who would be notified if the

\footnotetext{
${ }^{1}$ See, e.g.,Skinner (2007), Brown et al (2009), and DellaVigna (2009) for reviews. To be fair, as those papers and others have discussed, the evidence on whether and why people undersave is inconclusive (see, e.g., Scholz, Seshadri, and Khitatrakun 2006).

${ }^{2}$ See also Ashraf et al (2006) on a commitment contract for shorter-run saving in the Philppines, and Karlan et al (2011) and Kast et al (2012) on text messaging to encourage savings deposits in developing countries. In the U.S. workplaces, see, e.g., Madrian and Shea (2001), Benartzi and Thaler (2004), Carroll et al (2009), Beshears et al (2011), Choi et al (2011). Many U.S. policies do not use behavioral levers per se but presume undersaving; e.g., subsidized retirement saving through workplace 401(k)'s and the more broadly available IRAs, subsidized shorter-term saving through individual development accounts.

${ }^{3}$ See, e.g., Angletos et al (2001), Gerardi et al (2010), Lusardi and Tufano (2009), Meier and Sprenger (2010), Stango and Zinman (2009; 2011a).

${ }^{4}$ The planning/advice market tends to target households with substantial net worth and focus on asset allocation. The evidence on whether these services add value for investors is mixed at best (see, e.g., Bergstresser, Chalmers, and Tufano; Hackethal, Haliassos, and Jappelli 2012; Mullainathan, Noth, and Schoar 2011). Licensed credit counseling services (CCS's) do serve millions of overindebted consumers, but CCS workout programs have eligibility requirements that screen out many millions more. The rest of the market for debt advice (e.g., mortgage brokers) and workouts (e.g., debt settlement companies) has many offerings of suspect quality (see, e.g, Berndt, Hollifield, and Sandas 2010; Woodward and Hall; Wilshusen 2011).
} 
client fell off-track. Once signed up, the research team monitored repayments using "soft pulls" of the client's credit report (i.e., credit checks that do not impact the credit score because they are not used for underwriting purposes) and delivered clients monthly reminder messages (email or phone). We emphasize that the version of BoLT tested here is very much of the "proof of concept" variety: there is almost certainly room for improvement and adaptation in the product design, delivery, and administration, as we discuss in the Conclusion.

BoLT's "kitchen-sink" approach of using several levers to address multiple behavioral factors is modeled on Save More Tomorrow ${ }^{\mathrm{TM}}$ (SMaRT). But the institutional particulars are different. SMaRT piggybacks on the extensive workplace intermediation of retirement saving created by employers tax subsidies. Debt markets are far less intermediated in the U.S. (and elsewhere), and so we pilot-tested BoLT using a "direct-to-consumer" distribution channel. SMarT also has a key component in which it shifts the default action to saving more unless someone comes in and actively decides to reverse their decision, whereas with BoLT we help borrowers set a new plan but do not have a mechanism in this institutional setting to change the default action.

Our pilot sample of 465 individuals is drawn from the clientele of free tax-preparation services offered by the Community Action Project of Tulsa, Oklahoma. From January-April 2010, the research team approached persons waiting to get their taxes done at three of CAP's sites with an invitation to take a fifteen-minute survey in return for a \$5 gift card to QuikTrip, a local gas station and convenience store. ${ }^{5}$ Those who completed the survey and a consent form permitting credit report soft pulls were then randomized to either receive a BoLT offer or not. Baseline credit reports identify those with a potentially suitable debt.

The pilot results are merely suggestive, but they point to strong demand for new debt reduction products/services with behaviorally-motivated features. Among those randomly assigned to a BoLT offer, $41 \%$ signed up for some version of it. Conditional on BoLT take up, the take-up rates for escalating repayment schedules, peer support, and reminders were $41 \%$, $27 \%$, and $81 \%$.

Estimates of 12-month treatment effects offer some hope that BoLT-like approaches can produce their intended effects, although we caution that most of our results here are imprecisely estimated zeros. We measure impacts on financial condition using the random assignment to identify the causal effects of

\footnotetext{
${ }^{5}$ We tried adding to the sample during the 2011 tax season, but various operational issues-- including reduced number of tax sites available for this research, reduced traffic at tax sites due to unusually bad weather, and poor compliance by field personnel with the research design-- made what little additional data we obtained in 2011 unusable.
} 
BoLT and credit report data to glean some unbiased measures of financial condition. Unobtrusively captured administrative data has several potential advantages over survey data relying on subject selfreports. It can be cheaper to obtain. It can be less prone to biased attrition. It is less prone to reporting biases that may be correlated with treatment and unobserved determinants of outcomes (Karlan and Zinman 2008; Zinman 2009). In all we find some statistically weak evidence that BoLT reduces credit card balances over a 12-month horizon, and little evidence that BoLT affects auto balances or broader outcomes (credit scores, delinquency, line of credit utilization, or number of active debts).

This pilot informs several lines of inquiry in (household) finance, behavioral economics, and intertemporal choice. It is the first study we know of that takes the behavioral financial engineering approach used to interesting effect in asset markets (Benartzi and Thaler 2004; Ashraf, Karlan, and Yin 2006; Gine, Karlan, and Zinman 2010) and applies it to debt reduction. It provides novel data points on the demand for a new debt reduction product and for a social commitment device. And it is the first paper we know of that uses a randomized-control design to measure the impact of a debt reduction initiative. $^{6}$

The paper proceeds as follows. Section 2 describes our pilot setting and sample, BoLT product design and implementation, and research design and implementation. Section 3 describes BoLT demand and usage in the pilot. Section 4 estimates whether BoLT actually succeeded in helping people reduce debt over a 12-month horizon. Section 5 concludes by discussing prospects for improving BoLT’s design and implementation, including some speculation about various business models for offering BoLT on a large scale.

\section{Study Design and Implementation}

Sample Frame and Setting. Our sample frame for the study is drawn from the Community Action Project's (CAP) free Volunteer Income Tax Assistance (VITA) tax preparation service for low and moderate income (LMI) individuals. CAP is based in Tulsa, Oklahoma and provides a range of social services including early childhood education and first-time homebuyer's assistance. It runs one of the largest per-capita free tax preparation programs in the country, and delivered this service at eight different locations throughout Tulsa County during the 2010 tax season. CAP gave the research team

\footnotetext{
${ }^{6}$ See Collins and O’Rourke (2010) for a review of financial education and counseling evaluations.
} 
access to the three busiest sites, and the research team approached potential subjects at these sites from January 26 through April 15.

On-Site Process Flow and Sample Creation. High volume at the tax preparation sites resulted in long waiting times for many individuals visiting the CAP centers, and we used this downtime to enroll people into the study. The CAP receptionist or a surveyor from the research team would periodically ask people in the waiting room if they were interested in completing a survey about their financial wellbeing. The tax-preparation staff also encouraged people they were assisting to complete the survey after their tax-preparation session. Individuals were offered a \$5 gift card redeemable at a local gas station and convenience store as an incentive to participate in the survey. Interested individuals were directed to a member of the research team. People granting consent to participate in the study (by complete the survey and granting permission for the research team to do "soft pulls" of the subject's credit report that day, and going forward) were then interviewed

Survey interviews took about fifteen minutes and covered basic demographics, financial product use, respondent assessments of their household's financial condition, and some basic questions designed to measure behavioral factors (time-inconsistency, exponential growth bias, and limited attention). The complete survey instrument is reproduced as Appendix 1. 1432 interviews were completed over the 2.5 months of surveyor/marketer operations. Upon completing the survey, the interviewer used a random number generator in Excel to randomly assign the interviewee (the subject) to either receive a BoLT offer (details below in II-D), following the survey, or not. ${ }^{7}$ This process and assignment was not visible to the interviewee.

Analysis Sample Characteristics and Randomization Integrity. Our sample frame consists of 465 individuals that qualified for BoLT by having an auto loan or a credit card with a positive balance at baseline. ${ }^{8}$ Of these, 238 were assigned to be offered BoLT (treatment) and 227 assigned to not receive BoLT (control).

\footnotetext{
${ }^{7}$ Initially, in "Phase 1" of the pilot, all individuals who completed the survey were randomized to get a BoLT offer or not. Beginning on March 1, 2010, Phase 2 only randomized individuals with qualifying debt who also expressed an interest in reducing their debt when prompted by the surveyor. We control for this change in sample frame construction when estimating BoLT treatment effects.

${ }^{8}$ We arrive at 465 after excluding 31 individuals who were surveyed by surveyor/marketers fired for noncompliance with the research design, and 6 individuals with nonresponse to multiple questions in the baseline survey.
} 
Table 1 presents checks of randomization integrity. Column 4 presents p-values for estimates of differences between the BoLT-offer group (Column 2) and the control group (Column 3), for each of several credit report and survey variables. The number of statistically significant differences is about what one would expect to find by chance. The table also reports p-values for F-tests from OLS regressions ( $\mathrm{N}=465)$ of whether the subject is assigned to a BoLT offer on different combinations of baseline variables: credit report only, survey variables only, or all baseline variables. None of these groups of variables jointly predicts treatment assignment.

The baseline variables in Table 1 also describe our sample. Starting at the top of Column 1, the sample average credit score is 604, which falls roughly in the bottom quarter of all individuals who have a FICO credit score in the United States. ${ }^{9}$ Note the substantial variation in scores (SD=95). Mean credit card $(\$ 2,447)$ and auto loan balances $(\$ 5,546)$ are low relative to U.S. averages (M. Brown et al. 2011), but also show substantial variance within our sample.

Survey questions on demographics find that $74 \%$ of the sample is female, with a mean age of 44 and low incomes. $75 \%$ of the sample reports a total household income of $\$ 30,000$ or less, and only $2 \%$ report \$50,000 or more. This is expected given the sample frame: clients of a free tax preparation service that screens on income (\$50,000 max with dependents, $\$ 40,000$ single) and often requires long wait times. 53\% of the sample has some college education, and 19\% report earning a bachelor's degree or more.

Survey questions on financial condition and product usage indicate prevalent financial distress and (expensive) credit usage in this sample. 43\% report that their household's financial situation is "not very good" or "bad". 16\% report being forced to move due to financial difficulties during the last 12 months, and 32\% report that adults in the household had to cut back on food. 36\% report being turned down for credit recently, and 58\% report being discouraged from applying. Self-reported financial product usage in the last two years spans both mainstream and “alternative” products. 94\% have had a checking account, although only 31\% have had a home mortgage (due in part to low homeownership rates in this sample). 62\% have had a credit card, and 54\% an auto loan. Usage of expensive smalldollar loan products_-bank overdrafts, payday loans, auto title loans, refund anticipation loans, pawnsappears prevalent despite the tendency for survey respondents to underreport borrowing on these types of instruments (Karlan and Zinman 2008; Zinman 2010).

\footnotetext{
9 “Understanding My FICO Score”: http://www.myfico.com/Downloads/Files/myFICO_UYFS_Booklet.pdf
} 
The baseline survey also contains questions designed to proxy for some of the behavioral biases that motivate BoLT’s design. Two hypothetical choices over smaller-sooner vs. larger-later rewards, for today vs. 1-month from today, and 6-months vs. 7-months from today, give us a standard, if coarse, measure of time-inconsistency (Ashraf, Karlan, and Yin 2006; Meier and Sprenger 2010). 20\% of respondents exhibit "standard" reversals on this, exhibiting impatience on the today vs. 1-month choice, and patience on the 6- vs. 7-month choice. ${ }^{10}$ As a second proxy for costly self-control problems, we ask the following: "I often find that I regret spending money; I wish that when I had cash, I was better disciplined and saved my money rather than spent it.” 77\% of respondents say that they strongly or somewhat agree with that statement. We glean a coarse measure of (limited) attention from a question about how often someone thinks about their financial situation (30\% say something less than “a lot”). We also construct a measure of exponential growth bias (or, more agnostically, of numeracy) from open-ended, intuitive responses to a question on population growth: $49 \%$ underestimate, 34\% overestimate, and $6 \%$ provide more or less the correct answer (plus or minus $15 \%$ of the exact correct answer). ${ }^{11}$

Details on BoLT Product Design, Offer Randomization, Intake, and Follow-up Administration. We designed BoLT with an eye towards offering a simple debt reduction product that counters behavioral biases toward indebtedness and ultimately could be offered to a mass market of consumers interested in accelerating debt repayment (and/or controlling new borrowing). As noted at the outset, the version of BoLT piloted here has three features: a planning/goal setting tool, a commitment option, and reminders. We are not positing that the particular features tested here are necessarily optimal, and discuss several possibilities for testing augmentations and adaptations in the Conclusion, in particular methods of switching the default action (e.g., through a bill-payer service).

Everyone completing a survey was randomly assigned to receive a BoLT offer or not, immediately upon finishing the survey (the randomization was conducted in real-time and unbeknownst to the subject, on the market/surveyor's laptop). Subjects assigned to the control group received their survey

\footnotetext{
${ }^{10}$ Interestingly, $12 \%$ exhibit the opposite reversal. This is commensurate with what we've seen in other studies and settings, and it's possible that this response is an indicator of confusion or inattention re: the survey. But we have yet to see a good explanation/theory that explains the full pattern of responses to the standard timeinconsistency questions. When using survey responses to these questions in our regressions, we use the full set of categorical responses: patient on both, impatient on both, impatient now and patient later, patient now and impatient later.

${ }^{11}$ As discussed in section II-D, BoLT's design is also loosely motivated by loss aversion, but we do not have a measure of loss aversion from the survey.
} 
compensation (a gift card), and thanks for their time. Subjects assigned to receive a BoLT offer also got a marketing pitch with a brief overview of BoLT’s features. Subjects expressing interest in BoLT were then taken through a more thorough, but still brief (typically twenty minutes from start-to-finish for those who signed up), planning and set-up process.

Step 1 of the BoLT marketing and intake process is identifying a suitable debt. In the pilot, this involved the marketer inviting the prospective client to discuss the client's credit report, and using this information and the client's recall to identify an auto loan or credit card account with a nontrivial balance and a high APR (credit reports do not include pricing information). ${ }^{12}$ Due to operational constraints in the pilot (namely making BoLT marketing and intake as simple and quick as possible in order to capture as large as a sample as possible while they were waiting to get their taxes done), we offered BoLT for only a single loan per client. This is not necessarily the optimal design, as we discuss in Sections IV and V.

Step 2 of the intake process is using a decision aid to help make a concrete plan for paying down debt more quickly. The idea is to present someone with a simple but effective planning/goal setting tool that counters the many potential cognitive obstacles to motivating, setting, and implementing a realistic debt reduction goal, including limited numeracy or literacy (Lusardi and Tufano 2009), exponential growth bias re: interest expense (Soll, Keeney, and Larrick 2011; Stango and Zinman 2011b), information overload (Iyengar, Huberman, and Jiang 2004; Bertrand et al. 2010), and planning fallacies (Peetz and Buehler 2009). In the pilot studied here, the tool was a simple repayment schedule calculator (Appendix 2), used by the on-site surveyor/marketer to help interested clients craft a realistic goal and schedule for accelerating the repayment of a single credit card or auto loan debt. Marketers typically reviewed a number of hypothetical payment schedules with a client to demonstrate the potentially dramatic reductions that small increases in monthly payments can have on repayment time and total interest paid (demonstrating this is a goal of one the new credit card disclosures required by the CARD Act). Once someone drafted a repayment schedule featuring the usual equal monthly payments, marketers presented the option of a payment schedule that escalated \$10 each month (e.g., \$25 in month 1, \$35 in month 2, \$45 in month 3.......$^{13} 41 \%$ of those offered BoLT made an accelerated repayment

\footnotetext{
${ }^{12}$ Marketers also screened for prepayment penalties, which are non-existent for credit cards (being lines of credit) and rare for auto loans.

${ }^{13}$ In a lower-touch version of BoLT, we expect that Steps 1 and 2 of the intake process might be integrated using a single decision aid; in some settings, said decision aid could use various types of (passively captured) baseline data to make algorithm-based, customized recommendations.
} 
plan, and $41 \%$ of plans featured escalating repayments. The main "take-away" for BoLT clients was a repayment schedule printout showing their new, accelerated plan side-by-side vs. their old repayment pattern.

Step 3 of the process is the offer of a commitment device, in this case the option of signing up one or more "peer supporters", who would be notified and asked to provide encouragement (but not financial support), in the event that the BoLT client fell behind on her repayment schedule. (The scripts used for peer supporter notification are presented in Appendices 3a and 3b.) The approach is to use the ex-ante prospect of peer notification, and any ex-post peer encouragement, as additional incentives for sticking to the debt reduction plan. The idea comes from work in social psychology on various forms of peer pressure (e.g., Cialdini and Goldstein 2004), and the application is based loosely on other low-intensity peer mechanisms that have been built to support goal pursuit (e.g, Stickk.com, 43things). A differentiating factor here, however, is that a third-party (not the supporter or the supported) monitors progress. $^{14}$

Individuals who made a repayment plan in Step 2 were offered the Peer Support option, with a few exceptions. ${ }^{15}$ A client selecting the option simply gave the marketer contact information for one or more friends, family members, and/or co-workers. $27 \%$ of those making a BoLT repayment plan enlisted one or more peer supporters. The modal number of peer supporters is one, with $34 \%$ of those choosing the peer support option listing two or more.

The fourth step of the BoLT intake process had the client choose whether she wished to receive monthly reminders by phone or email ( $44 \%$ chose phone, $37 \%$ chose email, and $19 \%$ opted out). The idea here is to counter limited attention by keeping the client's debt reduction goal and plan at "top of mind” (see, e.g., Karlan et al. 2011 and cites therein). Stand-alone reminders may be particularly important in settings, like our pilot, where the institutional or contractual environment does not tend to produce regular follow-up contacts (monthly statements, advertising). Reminders were administered by research team staff and the scripts are presented in Appendix 3c.

\footnotetext{
${ }^{14}$ Kast et al (2012) have a similar monitoring technology (bank monitoring of savings deposits) in their Savings Buddy treatment.

${ }^{15}$ Midway through the pilot (at the start of Phase 2) we started randomizing the peer support offer in conjunction with added sample filter described in footnote 7 . The idea was to start building a large enough sample size to isolate the effect of the peer support component (see the Conclusion for related discussion). Said sample has indeed started to build: only 55 of those in BoLT offer group were randomized into a peer support offer (and payment schedule) or not; the other 27 in the BoLT offer group were offered the payment schedule only. So we do not have a large enough sample with peer support randomization here to make sharp inferences; we plan to pool this data with data gleaned from future projects.
} 
Besides administering reminders, the other follow-up administration involved in this implementation of BoLT is monitoring repayment progress so that peer supporters can be notified if the supported client falls behind their scheduled repayment plan. The research team does this monitoring monthly by comparing information from the client's latest credit report (obtained with a soft pull) to her BoLT repayment plan.

\section{BoLT Demand, Plans, and Performance}

Take Up. Table 2 Panel A summarizes the key take-up rates. 41\% of those offered BoLT made a plan to accelerate payment on a credit card or auto loan debt (Panel B shows that credit cards were somewhat more popular). ${ }^{16}$ Of those making a plan, $41 \%$ chose escalating instead of fixed monthly payments (e.g., \$15, \$25, \$35... instead of \$20 each month). 27\% signed up a peer supporter, and 81\% signed-up to receive phone or email reminders.

Predictors of Take Up. Table 3a estimates OLS correlations between the BoLT take-up decision and baseline individual characteristics gleaned from the credit report and survey. Sample size is only 156 here in Table 3a because we limit the analysis to those offered BoLT in phase 1 of the study, since those in phase 2 were pre-screened for willingness to participate in a debt reduction strategy and thus take up was nearly $100 \%$ in phase 2 . The small sample here limits our ability to make strong inferences on predictors of take up.

Table 3a Column 1 shows estimates when only baseline credit report variables are included in the predictive model, along with several fixed effects detailed below. There is weak evidence of a statistical relationship between take up and the baseline credit characteristics (the p-value from a joint F-test of the three variables is 0.15 ), but the magnitudes implied the coefficients are quite small. The bottom rows of the table show that take up is strongly correlated with the week that someone entered the tax site, but not day-of-the-week, location, or identity of the surveyor/marketer. These fixed effect results hold regardless of which variables we include on the right-hand-side (RHS); one can see this reading across columns.

Table 3a Column 2 shows results when only basic demographics (collected from the survey) are included on the RHS. The point estimates suggest, not surprisingly, that extreme poverty (household

\footnotetext{
${ }^{16}$ We calculate this take-up rate based only on the 156 BoLT offers in Phase 1, because in Phase 2 we randomized only among people who expressed interest in a debt reduction product (and hence take-up rates are much higher in Phase 2). See footnote 7.
} 
income $<\$ 10,000$ a year) depresses take up. It also appears that take up may be U-shaped in education. Column 3 shows results when only proxies for behavioral variables are included on the RHS. No strong patterns emerge with respect to our proxies for costly self-control, exponential growth bias, and limited attention. Column 4 show results when only proxies for household financial condition and product use are included.

Table 3a Column 5 includes all of the credit report and survey variables used in any of the previous specifications. Few sharper inferences on individual correlates emerge, but the joint significance tests are revealing: both the credit report variables (p-value 0.09) and the survey variables (0.05) are jointly significant, and taken together these RHS variables have a p-value of 0.004 . This bodes well for future BoLT demand analysis on larger samples.

Table 3b estimates OLS correlations between the BoLT peer support take-up decision and baseline individual characteristics gleaned from the credit report and survey. (Recall that means of these baseline variables are presented in Table 1 Column 1.) The sample size is larger here ( $\mathrm{N}=211)$ than for BoLT payment plan take up (in Table 3a) because we can include phase 2 observations here. Nevertheless the sample remains too small in most cases to make strong inferences on individual variables.

Table 3b Column 1 shows estimates when only baseline credit report variables are included in the predictive model along with the fixed effects detailed above. There is no evidence of statistically or economically strong relationships between peer support take up and the baseline credit characteristics. The bottom rows of the table show that take up is strongly correlated with the week that someone entered the tax site and the identity of the surveyor/marketer (the latter result suggests that salesmanship matters, in keeping with Duflo et al (2006)). These fixed effect results hold regardless of which variables we include on the RHS; one can see this reading across columns.

Table 3b Column 2 shows results when only basic demographics (collected from the survey) are included on the right-hand-side (RHS). Peer support take up falls by half a percentage point for each year of age, suggesting that interest in getting peers involved in one’s personal finances may differ across cohorts. None of the other results is particularly suggestive. Column 3 shows results when only proxies for behavioral variables are included on the RHS. A striking result here is that timeinconsistency does not strongly correlate with take up; rather, patience at both horizons (today vs. 1month; 6-months vs. 7-months) is strongly and positively correlated with take up. In contrast, the regret spending point estimates suggest that regret may be positively correlated with take up. So the evidence on whether peer support appeals more to individuals with costly self-control problems is surprising (it 
seems instead to appeal more to more-patient people) and mixed. No strong patterns emerge with respect to our proxies for exponential growth bias or limited attention. Column 4 show results when only proxies for household financial condition and product use are included. Mortgage and payday loan use are both negatively correlated with peer support take up at 90\% confidence.

Table 3b Column 5 includes all of the credit report and survey variables used in any of the previous specifications. The point estimates on most of the variables do not change appreciably from the previous specifications. Overall, neither the credit report nor the survey variables (nor the two groups jointly) predict peer support take up; e.g., the p-value on the F-test for all of the credit report and survey variables is 0.38 .

BoLT Target Loan and Plan Characteristics. Table 2 Panel B describes the loans targeted by the 136 BoLT repayment plans in our sample; recall that each client could use BoLT for only one loan. 73 clients made plans for a credit card account, and 63 for an auto loan. The mean baseline interest rate on BoLT covered credit cards was an estimated 18\% (SD = 6\%), for auto loans it was 12\% (SD=5\%). These APRs are based on client self-reports and industry averages because credit reports do not contain pricing information. Mean (median) principal amount at baseline, based on the credit report, was \$2424 (\$1129) for BoLT credit cards, and \$9567 (\$9298) for auto loans. BoLT clients generally made plans to modestly increase payments; from \$97 (\$64) to \$115 (\$75) on credit cards, and from \$312 (\$325) to \$338 (\$356) on auto loans. Implementing these modest increases would produce dramatic reductions in the repayment horizon (and hence in total interest paid over the life of the loan): from 42 months to 19 months remaining at the medians of the BoLT credit card distributions (assuming no additional charges), and from 45 months to 32 months for the auto loans. 


\section{Does BoLT Work as Intended? Empirical Strategy and Results}

Descriptive Statistics on Performance. Table 2 Panel C describes BoLT client performance with their plans over the first 12 months post-take up. We measure performance by comparing the BoLT plan's targeted principal balance for a given month to the loan's balance reported in the credit report, adjusting for any credit reporting delays by lenders, which are typically one to three months. These descriptive estimates of performance suggest that about half of BoLT clients are on-schedule at the 12month mark. We do not find marked differences in the characteristics of targeted loans that are on-track vs. off-track.

Is a $51 \%$ on-track rate for debt reduction goals high or low? If debt reduction goals suffer from low follow-through (as is the case, e.g., with smoking cessation and weight loss), then $51 \%$ may be (quite) high. Randomizing subjects into either a BoLT offer or a control group (no offer) enables us to address this question using a valid counterfactual (i.e., a randomized control group).

Estimating Treatment Effects Using Random Assignment (and a Matching Estmator). Our empirical strategy for estimating the "treatment" (causal) effects of BoLT starts with the following OLS or median regression specification:

(1) $\mathrm{f}\left(Y_{\text {it }}\right)=\mathrm{a}+\mathrm{bBoLTOffer}$ it0 $+\mathrm{c} X_{\text {it } 0}+\mathrm{e}$

Where i indexes individual borrowers and t time. An outcome of interest $Y$ (balances, credit scores, etc.) is measured from soft pulls of individual credit reports. We have up to three credit reports per individual on everyone in the sample, from different points in time (baseline, 6-months after entering the sample, and 12-months after), that we can use to measure $Y$ (in levels, changes, or averaging across follow-up observations). Our regressor of interest is an indicator for random assignment to a BoLT offer, conducted at the individual level. Hence our coefficient of interest, b, captures an intent-to-treat (ITT) effect. ITT estimates permit inference about what happens when something like BoLT is made available to a market of borrowers with high-interest debt. $X$ is a vector of randomization strata (surveyor, location, time) and control variables (for baseline survey and credit report variables). We calculate heteroskedasticity-robust (Huber-White) standard errors when using OLS, and bootstrap standard errors using 100 replications when using median regression.

We also estimate specifications after "stacking” the three observations per individual (baseline, 6month follow-up, and 12-month follow-up) and replacing the baseline characteristics $X$ with borrower 
fixed effects, and dummies for the timing of each observation. In these specifications the Offer variable takes the value of zero for everyone at baseline $(\mathrm{t}=0)$, and the value of one for those in the treatment group at the 6-month and 12-month follow-up observations.

Our main outcomes of interest are different measures of (changes in) credit card balances (total across all of i's credit card accounts) and auto loan balances (total across all auto loans). Even though BoLT targets a single loan, we focus on individual- (loan type-) level outcomes for two reasons. The first is conceptual: although BoLT's first-order effects presumably work through the targeted loan, we are interested in broader measures of indebtedness and financial condition that allow for spillovers (e.g., substitution or complementary between BoLT-targeted debt reductions and other debt reductions). The second is statistical: we lack a good way of identifying which loan someone in the control group would target if they used BoLT (i.e., our loan-level predictions are quite noisy). ${ }^{17}$

Table 4a reports BoLT treatment effect estimates on the borrower's total credit card balances. Panel A reports results for the full sample. Column 1 estimates our OLS baseline control specification (model (1)) with 12-month follow-up level balances as the outcome. Column 2 uses the same specification but with $\log (1+$ balances) on the left-hand-side (LHS). Column 3 uses the baseline to 12-month change in balances on the LHS. Column 4 uses the average of the 6- and 12-month follow-ups on the LHS. Column 5 uses the average change, across baseline to 6-months and baseline to 12-months, on the LHS. Column 6 uses median regression instead of OLS, with 12-month level balances on the LHS. Column 7 and 8 use the individual fixed effects specification (model (2)), with 12-month level and log(1+balances) on the LHS. Panel B reproduces the same specifications for the sub-sample with nonzero credit card balances at baseline. We report results for this sub-sample because it may be the case that only those with credit card debt at baseline would have their subsequent credit card balances affected by BoLT.

Reading across the columns in the two panels, one sees a preponderance of negative coefficients on the BoLT Offer variable: 12 out of 16. This suggests that BoLT has its intended effect of helping borrowers reduce credit card debt. Moreover, two of the specifications $n$ the full sample (with balances measured in changes) show statistically significant reductions. However, one must be wary about making firm inferences from these results: they are not strong in the statistical sense. E.g. these results

\footnotetext{
${ }^{17} 71 \%$ of our sample had multiple credit cards, $40 \%$ had multiple auto loans, and $34 \%$ had a least one credit and at least one auto loan. In future studies inferential power could be increased by offering BoLT at a more aggregated level (e.g., over total credit card balances), and/or by restricting BoLT offers to certain debt classes (e.g., credit cards only). Additional restrictions based on loan characteristics that are observable in the credit report (e.g., credit card with largest balance) would further increase power, but there is a tradeoff with external validity.
} 
are not particularly robust to the definitional details (in particular, the functional form) of balances. Trimming outliers from the LHS, or estimating treatment effects for median or log balances instead of mean levels, do not reliably produce negative coefficients.

Table $4 \mathrm{~b}$ is organized the exact same way as Table 4a, but for auto loan balances instead of credit card balances. Again we see a preponderance of treatment effect coefficients suggesting debt reduction: 12 out of 16 . But here we do not find any statistically significant reductions.

Table 5 reports results for additional key outcomes that plausibly capture more comprehensive aspects of the liability side of the balance sheet than a particular debt class like credit card balances (Table 4a) or auto loan balances (Table 4b). The motivation for examining these outcomes—credit scores, delinquencies, active trade count, and utilization rate of available credit—is threefold. First, BoLT could improve these outcomes if it succeeds in reducing debt loads and encouraging timely repayment. Second, BoLT could have perverse effects on these outcomes if it causes borrowers to be unduly focused on a particular debt and lose sight of the "big picture" of debt management. Third, some of these outcomes have "better-behaved" statistical distributions than balances do, leading to more precise estimates of treatment effects and hence inferences that might be missed by focusing on (relatively noisy) balance outcomes.

Table 5a reports BoLT treatment effect estimates on credit scores over the 12-month follow-up horizon. We use the same specifications here as in Table 4, with two exceptions. We do not use $\log$ (credit score) because scores are normally distributed by construction. And we examine only the full sample. We do not find any significant effects, and the confidence intervals contain only fairly small effects (up to 18 points) on scores. Hence one can infer that this implementation of BoLT did not have large effects, positive or negative, on credit scores over the one-year follow-up period.

Tables 5b-d find no evidence that BoLT affects delinquencies, total trade lines (i.e., total count of debts that are active or still owed), or credit line utilization (sample size on this variable is depressed by missing variables on credit limits).

\section{Conclusion}

Borrow Less Tomorrow (BoLT) is new, behaviorally motivated approach to developing a mass market debt reduction product. It combines a decision aid, commitment option, and reminders designed to help people make realistic, actionable plans to reduce (or control) high-interest debt. We pilot tested BoLT in a sample of free tax-preparation clients in Tulsa, Oklahoma, during the 2010 tax season. We 
find some evidence of strong demand for BoLT (41\% of those offered it made a plan) and for its component features: of BoLT users, $27 \%$ took peer support, $41 \%$ made an escalating repayment plan, and $81 \%$ were sent reminders. We find positive but statistically weak evidence that BoLT has its intended effects on debt reduction.

We posit several caveats to consider when interpreting these results. First, our small sample size and other research design elements of the pilot (offering BoLT for only a single loan, offering a choice between a credit card and an auto loan) limit our statistical power. This precludes sharp inferences on BoLT's overall effectiveness or its underlying mechanisms. Second, the external validity of our results is uncertain. Free tax-preparation clients are but a small subset of BoLT's target market. There are many reasons to think that the pilot version of BoLT is not the optimal one. Third, there are many design decisions with similar rationales that may make important differences, and we only tested one set. Thus we cannot reject the theories behind the motivation; it may just require tinkering on design matters. In particular, we believe testing changes in the default option, through e.g., a bill-paying system, may hold particular promise. This would thus mimic SMarT even more closely.

The limitations of the present study highlight several tacks for future research. We view the BoLT design as modular and adaptable to different markets and business models. One could (and probably should) offer a broader range of planning and commitment options; e.g., providing an option for using BoLT to manage total credit card balances (instead of focusing only on one account, as we did in the pilot). Balance targets could allow for goals and commitment over controlling new borrowing as well as reducing existing debts. Commitment options could be expanded to include additional "soft” options (setting up automatic payments from checking to debt accounts) and/or hard options (e.g., a client authorizing the BoLT vendor/administrator to cut off access to charging privileges in the event of noncompliance with the plan). Online decision aids might take the place of "high-touch" marketing or counseling sessions. Direct marketing could be used to make customized recommendations. Follow-up messaging might include feedback along with (or instead of) reminders. And of course, randomized testing on large samples can be used to evaluate the (cost-) effectiveness of these different design features (and version thereof) and packages.

Larger samples would also permit further tests of heterogeneity, specifically for instance which behavioral factors predict participation, and for which behavioral factors treatment effects are largest. Different BoLT features are designed to operate on different behavioral biases; unpacking the individual and relative contributions of BoLT components can reveal something about the relative importance of 
different behavioral factors. Adding baseline data that elicits direct measures of behavioral factors would permit estimation of demand, and of heterogeneous treatment effects, that would further enrich theory-testing.

We close with some speculation about prospects for "scaling up" BoLT to reach a broader market and generate large samples for research and development. It seems to us that many types of businesses could benefit from offering BoLT or like approaches, perhaps on a subscription basis or as part of a larger bundle of services. Bill payers, other payment platforms (e.g., mobile wallets), or credit bureaus could add BoLT to their bundles. Employee benefit providers, financial advisors, and advice engines could use BoLT to help broaden their financial wellness packages beyond retirement savings and asset allocation. Debt collectors or credit counseling agencies could offer BoLT to clients who successfully repay. Before scale-up, however, further tests should be conducted on design and marketing until stronger and more consistent impacts are found.

The use of behavioral approaches for debt reduction is in its infancy. The pilot study here is a baby step, hopefully in the right direction. 
Tables

\begin{tabular}{lcccc}
\hline Table 1: Sample Characteristics & & & & \\
\hline \hline & Control & $\begin{array}{c}\text { Treatment }= \\
\text { offered BoLT } \\
\mathrm{N}=238\end{array}$ & $\begin{array}{c}\text { Difference } \\
\text { (p-value) }\end{array}$ & Full Sampl \\
& $\mathrm{N}=227$ & $\mathrm{~N}=465$ \\
\hline Baseline Credit Report Variables & & & & \\
\hline Baseline Credit Score & 608.70 & 598.60 & 0.15 & 603.53 \\
& {$[96.55]$} & {$[94.61]$} & {$[95.59]$} \\
Baseline Total CC Balances (\$) & 2106.08 & 2771.53 & 0.27 & 2446.68 \\
& {$[4421.945]$} & {$[5635.71]$} & {$[5085.04]$} \\
Baseline Total Auto Loan Balances (\$) & 5023.31 & 6083.63 & 0.20 & 5566.01 \\
& {$[7133.67]$} & {$[7649.89]$} & {$[7413.44]$}
\end{tabular}

F-test: credit variables correlated with treatment assignment?

\begin{tabular}{|c|c|c|c|c|}
\hline \multicolumn{5}{|l|}{ Baseline Survey Variables } \\
\hline Male Respondent & $71 \%$ & $76 \%$ & 0.43 & $74 \%$ \\
\hline Age & 44.59 & 43.72 & 0.25 & 44.14 \\
\hline Yearly HH Income $<\$ 10,000$ & $18 \%$ & $12 \%$ & 0.06 & $15 \%$ \\
\hline Yearly HH Income $\$ 10 k-\$ 20 k$ & $29 \%$ & $29 \%$ & 0.99 & $29 \%$ \\
\hline Yearly HH Income $\$ 20 \mathrm{k}-\$ 30 \mathrm{k}$ & $30 \%$ & $32 \%$ & 0.50 & $31 \%$ \\
\hline Yearly HH Income $\$ 30 \mathrm{k}-\$ 40 \mathrm{k}$ & $17 \%$ & $20 \%$ & 0.53 & $18 \%$ \\
\hline Yearly HH Income $>\$ 40 k$ & $6 \%$ & $8 \%$ & 0.74 & $7 \%$ \\
\hline Education: < HS Graduate & $7 \%$ & $6 \%$ & 0.65 & $7 \%$ \\
\hline Education : HS Graduate / GED & $22 \%$ & $22 \%$ & 0.86 & $22 \%$ \\
\hline Education : Some College, AA degree or Trade School & $53 \%$ & $53 \%$ & 0.80 & $53 \%$ \\
\hline Education: Bachelors Degree or more & $18 \%$ & $19 \%$ & 0.89 & $19 \%$ \\
\hline Time Inconsistent: Standard & $18 \%$ & $22 \%$ & 0.31 & $20 \%$ \\
\hline Time Inconsistent: Nonstandard & $12 \%$ & $12 \%$ & 0.63 & $12 \%$ \\
\hline Time Inconsistent: Always impatient & $15 \%$ & $13 \%$ & 0.77 & $14 \%$ \\
\hline Time Inconsistent: Always patient & $55 \%$ & $53 \%$ & 0.85 & $54 \%$ \\
\hline Compound Interest: Linear Approximation & $26 \%$ & $33 \%$ & 0.27 & $29 \%$ \\
\hline Compound Interest: Underestimate (even less than linear) & $22 \%$ & $18 \%$ & 0.47 & $20 \%$ \\
\hline Compound Interest: Overestimates & $33 \%$ & $35 \%$ & 0.60 & $34 \%$ \\
\hline Compound Interest: Missing/unavailable & $12 \%$ & $8 \%$ & 0.52 & $10 \%$ \\
\hline Compound Interest: Correct +-300 & $7 \%$ & $6 \%$ & 0.27 & $6 \%$ \\
\hline Thinks About Financial Situation A Lot? & $73 \%$ & $68 \%$ & 0.11 & $70 \%$ \\
\hline Regrets Spending / Lacks Discipline: Strongly Agree & $39 \%$ & $38 \%$ & 0.67 & $39 \%$ \\
\hline HH Financial Situation "OK or better" & $55 \%$ & $59 \%$ & 0.43 & $57 \%$ \\
\hline HH Financial Situation "Not Very Good" & $30 \%$ & $29 \%$ & 0.66 & $29 \%$ \\
\hline HH Financial Situation "Bad" & $15 \%$ & $12 \%$ & 0.58 & $14 \%$ \\
\hline Turned down recently for credit? & $35 \%$ & $37 \%$ & 0.51 & $36 \%$ \\
\hline Discouraged from applying? & $53 \%$ & $62 \%$ & 0.01 ** & $58 \%$ \\
\hline Financial Distress Index & 1.68 & 1.70 & 0.50 & 1.69 \\
\hline \multicolumn{5}{|c|}{ (average of late bill payment, forced move, and food cutback responses) } \\
\hline \multicolumn{5}{|c|}{ Financial Products Held In Past 2 Years (dummies): } \\
\hline Checking Account & $93 \%$ & $95 \%$ & 0.56 & $94 \%$ \\
\hline Savings Account & $65 \%$ & $69 \%$ & 0.43 & $67 \%$ \\
\hline CD/Investment Account & $33 \%$ & $31 \%$ & 0.38 & $32 \%$ \\
\hline Credit Card & $63 \%$ & $62 \%$ & 0.80 & $62 \%$ \\
\hline Refund Anticipation Loan & $6 \%$ & $9 \%$ & $0.05^{\star}$ & $8 \%$ \\
\hline Payday Loan & $15 \%$ & $19 \%$ & 0.12 & $17 \%$ \\
\hline Auto Loan & $56 \%$ & $53 \%$ & 0.39 & $54 \%$ \\
\hline Auto Title Loan & $21 \%$ & $18 \%$ & 0.83 & $20 \%$ \\
\hline Negative Checking Balance / Overdraft & $52 \%$ & $50 \%$ & 0.59 & $51 \%$ \\
\hline Rent-to-own & $7 \%$ & $6 \%$ & 0.74 & $7 \%$ \\
\hline Pawn Loan & $9 \%$ & $9 \%$ & 0.09 & $8 \%$ \\
\hline Home Mortgage & $34 \%$ & $28 \%$ & $0.08^{\star}$ & $31 \%$ \\
\hline \multicolumn{3}{|l|}{ F-test: survey variables correlated with treatment assignment? } & 0.47 & \\
\hline \multicolumn{3}{|l|}{ F-test: all variables correlated with treatment assignment? } & 0.28 & \\
\hline
\end{tabular}




\begin{tabular}{|c|c|c|}
\hline Panel A. Take-up & Mean & Median \\
\hline BoLT takeup rate (i.e., made a plan to accelerate a debt repayment) & $41 \%$ & \\
\hline Escalating (not constant) repayment plan, conditional on BoLT take-up & $41 \%$ & \\
\hline Peer Support takeup rate, conditional on BoLT take-up & $27 \%$ & \\
\hline Reminder takeup rate, conditional on BoLT take-up & $81 \%$ & \\
\hline \multicolumn{3}{|l|}{ Panel B. Plans } \\
\hline BoLT plans for a credit card: count & 73 & \\
\hline Interest rate (est.) & $18 \%$ & $19 \%$ \\
\hline Baseline principal amount (\$) & 2424 & 1129 \\
\hline Time to repay without BoLT (months) & 140 & 42 \\
\hline Time to repay on BoLT schedule (months) & 52 & 19 \\
\hline Old monthly payment amount (\$) & 97 & 64 \\
\hline BoLT monthly target amount (\$) & 115 & 75 \\
\hline Old principal remaining at 12 months $(\$)$ & 2666 & 1434 \\
\hline BoLT principal remaining at 12 months (\$) & 2094 & 919 \\
\hline Change in principal remaining at 12 months $(\$)$ & 571 & 535 \\
\hline BoLT plans for an auto loan: count & 63 & \\
\hline Interest rate (est.) & $12 \%$ & $12 \%$ \\
\hline Baseline principal amount (\$) & 9567 & 9298 \\
\hline Time to repay without BoLT (months) & 126 & 45 \\
\hline Time to repay on BoLT schedule (months) & 41 & 32 \\
\hline Old monthly payment amount (\$) & 312 & 325 \\
\hline BoLT monthly target amount (\$) & 338 & 356 \\
\hline Old principal remaining at 12 months $(\$)$ & 7868 & 7770 \\
\hline BoLT principal remaining at 12 months (\$) & 6632 & 7100 \\
\hline Change in principal remaining at 12 months $(\$)$ & 1236 & 828 \\
\hline \multicolumn{3}{|l|}{ Panel C. Performance } \\
\hline$\%$ on-schedule after Month 12 & $51 \%$ & \\
\hline Credit card on-schedule rate after Month 12 & $52 \%$ & \\
\hline Auto loan on-schedule rate after Month 12 & $48 \%$ & \\
\hline Baseline interest rate: on-schedule after Month 12 & $14 \%$ & $15 \%$ \\
\hline Baseline interest rate: off-schedule after Month 12 & $17 \%$ & $17 \%$ \\
\hline Baseline principal amount (\$): on-schedule after Month 12 & 5863 & 4506 \\
\hline Baseline principal amount (\$): off-schedule after Month 12 & 5618 & 3656 \\
\hline
\end{tabular}




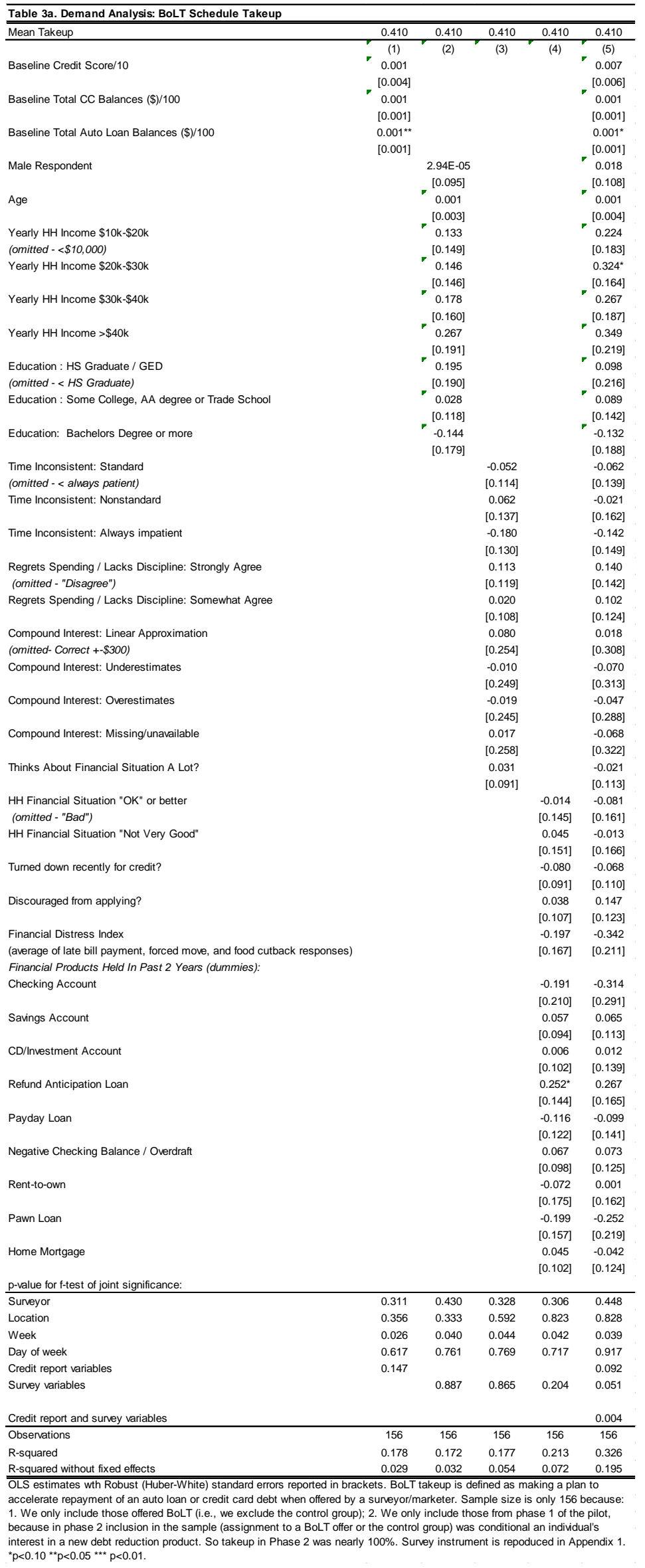


Table 3b. Demand Analysis: Peer Support Takeup

\begin{tabular}{|c|c|c|c|c|c|}
\hline Mean Takeup & 0.265 & 0.265 & 0.265 & 0.265 & 0.265 \\
\hline & (1) & (2) & (3) & (4) & (5) \\
\hline \multirow[t]{2}{*}{ Baseline Credit Score/10 } & -0.001 & & & & 0.002 \\
\hline & {$[0.003]$} & & & & {$[0.004]$} \\
\hline \multirow[t]{2}{*}{ Baseline Total CC Balances $(\$) / 100$} & 0.001 & & & & 0.001 \\
\hline & {$[0.001]$} & & & & {$[0.001]$} \\
\hline \multirow[t]{2}{*}{ Baseline Total Auto Loan Balances $(\$) / 100$} & $-1.62 \mathrm{E}-04$ & & & & $8.89 \mathrm{E}-05$ \\
\hline & [3.93E-04] & & & & {$[4.14 \mathrm{E}-04]$} \\
\hline Male Respondent & & 0.057 & & & 0.043 \\
\hline & & {$[0.071]$} & & & {$[0.079]$} \\
\hline Age & & $-0.005^{* *}$ & & & -0.004 \\
\hline & & [0.002] & & & {$[0.003]$} \\
\hline Yearly HH Income $\$ 10 \mathrm{k}-\$ 20 \mathrm{k}$ & & 0.016 & & & 0.012 \\
\hline (omitted $-<\$ 10,000)$ & & {$[0.108]$} & & & {$[0.124]$} \\
\hline Yearly HH Income $\$ 20 \mathrm{k}-\$ 30 \mathrm{k}$ & & -0.075 & & & -0.088 \\
\hline & & [0.103] & & & {$[0.115]$} \\
\hline Yearly HH Income $\$ 30 \mathrm{k}-\$ 40 \mathrm{k}$ & & -0.054 & & & -0.025 \\
\hline & & {$[0.116]$} & & & {$[0.123]$} \\
\hline Yearly $\mathrm{HH}$ Income $>\$ 40 \mathrm{k}$ & & -0.047 & & & -0.053 \\
\hline & & [0.135] & & & {$[0.152]$} \\
\hline Education : HS Graduate / GED & & -0.051 & & & -0.082 \\
\hline (omitted $-<$ HS Graduate) & & [0.138] & & & {$[0.161]$} \\
\hline Education : Some College, AA degree or Trade School & & 0.037 & & & 0.011 \\
\hline & & [0.092] & & & {$[0.107]$} \\
\hline Education: Bachelors Degree or more & & -0.121 & & & -0.101 \\
\hline & & {$[0.095]$} & & & {$[0.127]$} \\
\hline Time Inconsistent: Standard & & & -0.137 & & -0.137 \\
\hline (omitted $-<$ always patient) & & & [0.083] & & [0.094] \\
\hline Time Inconsistent: Nonstandard & & & $-0.218^{* *}$ & & $-0.266^{* *}$ \\
\hline & & & {$[0.085]$} & & [0.104] \\
\hline Time Inconsistent: Always impatient & & & $-0.164^{* *}$ & & $-0.193^{\star \star}$ \\
\hline & & & {$[0.081]$} & & {$[0.090]$} \\
\hline Regrets Spending / Lacks Discipline: Strongly Agree & & & 0.113 & & 0.117 \\
\hline (omitted - "Disagree") & & & [0.080] & & [0.100] \\
\hline Regrets Spending / Lacks Discipline: Somewhat Agree & & & 0.054 & & 0.044 \\
\hline & & & {$[0.077]$} & & [0.087] \\
\hline Compound Interest: Linear Approximation & & & -0.061 & & -0.118 \\
\hline (omitted-Correct +-\$300) & & & [0.194] & & [0.198] \\
\hline Compound Interest: Underestimates & & & -0.060 & & -0.131 \\
\hline & & & [0.195] & & [0.208] \\
\hline Compound Interest: Overestimates & & & -0.001 & & -0.083 \\
\hline & & & [0.193] & & [0.198] \\
\hline Compound Interest: Missing/unavailable & & & -0.089 & & -0.128 \\
\hline & & & {$[0.208]$} & & {$[0.228]$} \\
\hline Thinks About Financial Situation A Lot? & & & 0.022 & & -0.013 \\
\hline & & & {$[0.067]$} & & [0.084] \\
\hline HH Financial Situation "OK" or better & & & & $1.56 \mathrm{E}-04$ & -0.044 \\
\hline (omitted - "Bad") & & & & {$[0.106]$} & [0.120] \\
\hline HH Financial Situation "Not Very Good" & & & & -0.008 & -0.054 \\
\hline & & & & [0.110] & [0.123] \\
\hline Turned down recently for credit? & & & & 0.033 & -0.001 \\
\hline & & & & {$[0.067]$} & [0.074] \\
\hline Discouraged from applying? & & & & 0.005 & 0.033 \\
\hline & & & & [0.074] & [0.086] \\
\hline Financial Distress Index & & & & 0.111 & 0.088 \\
\hline (average of late bill payment, forced move, and food cutback responses) & & & & [0.120] & [0.132] \\
\hline Financial Products Held In Past 2 Years (dummies): & & & & & \\
\hline Checking Account & & & & 0.047 & 0.029 \\
\hline & & & & [0.143] & [0.192] \\
\hline Savings Account & & & & 0.057 & 0.024 \\
\hline & & & & {$[0.065]$} & {$[0.077]$} \\
\hline CD/lnvestment Account & & & & -0.059 & 0.009 \\
\hline & & & & {$[0.069]$} & [0.081] \\
\hline Refund Anticipation Loan & & & & 0.151 & 0.153 \\
\hline & & & & [0.133] & [0.147] \\
\hline Payday Loan & & & & $-0.155^{*}$ & -0.121 \\
\hline & & & & [0.089] & [0.093] \\
\hline Negative Checking Balance / Overdraft & & & & 0.099 & 0.087 \\
\hline & & & & {$[0.069]$} & [0.081] \\
\hline Rent-to-own & & & & -0.029 & 0.051 \\
\hline & & & & [0.124] & [0.126] \\
\hline Pawn Loan & & & & -0.012 & -0.037 \\
\hline & & & & [0.124] & [0.152] \\
\hline Home Mortgage & & & & -0.112 & -0.113 \\
\hline & & & & {$[0.068]$} & {$[0.075]$} \\
\hline -value for f-test of joint significance: & & & & & \\
\hline Surveyor & 0.013 & 0.031 & 0.005 & 0.003 & 0.005 \\
\hline Location & 0.266 & 0.295 & 0.250 & 0.136 & 0.682 \\
\hline Week & 0.000 & 0.003 & 0.003 & 0.0001 & 0.078 \\
\hline Day of week & 0.739 & 0.434 & 0.812 & 0.608 & 0.405 \\
\hline Credit report variables & 0.417 & & & & 0.694 \\
\hline Survey variables & & 0.386 & 0.197 & 0.474 & 0.393 \\
\hline Credit report and survey variables & & & & & 0.382 \\
\hline Observations & 211 & 211 & 211 & 211 & 211 \\
\hline R-squared & 0.228 & 0.254 & 0.257 & 0.263 & 0.339 \\
\hline R-squared without fixed effects & 0.005 & 0.049 & 0.067 & 0.045 & 0.155 \\
\hline
\end{tabular}


Table 4. BoLT Treatment Effects on Credit Card Balances

Panel A: Full Sample

" (1) (2) (3) (3) (4) (5) (7) (8)

Dependent Variable: Balance Measured as $\quad$ 12-month level log(1+12-month 12-month change Average(6-month, Average change $12-m o n t h ~ l e v e l \quad$ Level: baseline, 6- Log: baseline, 6level) from baseline 12-month) from baselne month, 12-month month, 12-month Control Group Mean or Median Any Treatment (OLS ITT)

Any Treatment (Median Regression ITT)

$\begin{array}{ccccc}-232.282 & 0.289 & -587.476^{\star} & -333.731 & -695.655^{\star \star} \\ {[300.419]} & {[0.303]} & {[321.762]} & {[294.412]} & {[322.013]}\end{array}$

[322.013] 2053.661 4.209

Any Treatment (Borrower Fixed Effects ITT)

RHS variables included: Randomization Phase? Surveyor fixed effects?

Location fixed effects

Baseline survey variables?

Baseline credit score?

Baseline card balances?

Baseline auto balances?

Borrower fixed effects?

Observations

R-squared/Pseudo R-squared

52.589
$[59.205]$

52.589
$[59.205]$

.

Panel B: Nonzero Card Balances at Baseline Only

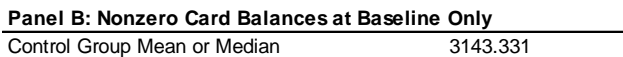

Any Treatment (OLS ITT)

$-192.526$

yes yes yes yes

yes

yes $\quad$ yes

yes yes

yes yes

yes yes

yes

no

Any Treatment (Median Regression ITT)

Any Treatment (Individual Fixed Effects ITT)

RHS variables included:

Randomization Phase?

Surveyor fixed effects?

Location fixed effects

Baseline survey variables?

Baseline credit score?

Baseline card balances?

Baseline auto balances?

Borrower fixed effects?

Observations

R-squared/Pseudo R-squared

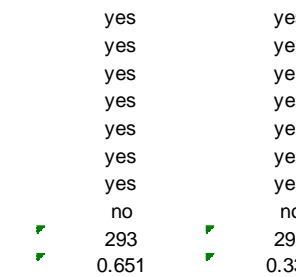

\begin{tabular}{|c|c|c|c|c|c|c|c|c|c|c|c|}
\hline yes & yes & & yes & & yes & & yes & & no & & no \\
\hline yes & yes & & yes & & yes & & yes & & no & & no \\
\hline yes & yes & & yes & & yes & & yes & & no & & no \\
\hline yes & yes & & yes & & yes & & yes & & no & & no \\
\hline yes & yes & & yes & & yes & & yes & & no & & no \\
\hline yes & no & & yes & & no & & yes & & no & & no \\
\hline yes & yes & & yes & & yes & & yes & & no & & no \\
\hline no & no & & no & & no & & no & & yes & & yes \\
\hline 293 & 293 & $=$ & 293 & 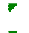 & 293 & $\checkmark$ & 293 & $\checkmark$ & 879 & 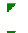 & 879 \\
\hline 0.336 & 0.173 & $F$ & 0.655 & $=$ & 0.184 & & 0.499 & $r$ & 0.042 & $F$ & 0.092 \\
\hline
\end{tabular}

fixed effect specifications. The baseline survey and credit report variables used here are the same as used in Tables $3 a$ and $3 b .{ }^{*} p<0.10{ }^{* \star} p<0.05{ }^{* \star} p<0.01$. 


\begin{tabular}{|c|c|c|c|c|c|c|c|c|}
\hline \multicolumn{9}{|l|}{ Panel A: Full Sample } \\
\hline & $(1)$ & $(2)$ & (3) & (4) & (5) & (6) & (7) & $(8)$ \\
\hline Dependent Variable: Balance Measured as & 12-month level & $\begin{array}{c}\log (1+12-m o n t h \\
\text { level })\end{array}$ & $\begin{array}{l}\text { 12-month change } \\
\text { from baseline }\end{array}$ & $\begin{array}{c}\text { Average(6-month, } \\
\text { 12-month) }\end{array}$ & $\begin{array}{c}\text { Average change } \\
\text { from baselne }\end{array}$ & 12-month level & $\begin{array}{l}\text { Level: baseline, } 6 \text { - } \\
\text { month, 12-month }\end{array}$ & $\begin{array}{l}\text { - Log: baseline, 6- } \\
\text { month, 12-month }\end{array}$ \\
\hline Control Group Mean or Median & 4791.313 & 3.871524 & -231.9956 & 4547.991 & -475.3172 & 0.000 & 4706.430 & 3.952 \\
\hline Any Treatment (OLS ITT) & -125.633 & 0.103 & -428.051 & 125.616 & -166.033 & & & \\
\hline & [505.133] & {$[0.332]$} & [537.275] & [405.650] & {$[429.801]$} & & & \\
\hline Any Treatment (Median Regression ITT) & & & & & & $\begin{array}{c}-12.452 \\
{[111.801]}\end{array}$ & & \\
\hline Any Treatment (Borrower Fixed Effects ITT) & & & & & & & $\begin{array}{l}-171.495 \\
{[386.350]}\end{array}$ & $\begin{array}{c}0.048 \\
{[0.244]}\end{array}$ \\
\hline \multicolumn{9}{|l|}{ RHS variables included: } \\
\hline Randomization Phase? & yes & yes & yes & yes & yes & yes & no & no \\
\hline Surveyor fixed effects? & yes & yes & yes & yes & yes & yes & no & no \\
\hline Location fixed effects & yes & yes & yes & yes & yes & yes & no & no \\
\hline Baseline survey variables? & yes & yes & yes & yes & yes & yes & no & no \\
\hline Baseline credit score? & yes & yes & yes & yes & yes & yes & no & no \\
\hline Baseline card balances? & yes & yes & yes & yes & yes & yes & no & no \\
\hline Baseline auto balances? & yes & yes & no & yes & no & yes & no & no \\
\hline Borrower fixed effects? & no & no & no & no & no & no & yes & yes \\
\hline Observations & 465 & 465 & 465 & 465 & 465 & 465 & 1,395 & 1,395 \\
\hline R-squared/Pseudo R-squared & 0.634 & 0.550 & 0.106 & 0.709 & 0.107 & 0.561 & 0.017 & 0.018 \\
\hline \multicolumn{9}{|c|}{ Panel B: Nonzero Auto Balances at Baseline Only } \\
\hline Control Group Mean or Median & 9539.879 & 7.616 & -1117.047 & 9124.668 & -1532.257 & 2628.000 & 9635.421 & 8.044 \\
\hline Any Treatment (OLS ITT) & -20.860 & -0.051 & -335.667 & 49.647 & -255.265 & & & \\
\hline Any Treatment (Median Regression ITT) & [975.892] & {$[0.498]$} & {$[1,006.173]$} & [737.019] & [760.155] & $\begin{array}{l}-290.069 \\
{[981.780]}\end{array}$ & & \\
\hline Any Treatment (Borrower Fixed Effects ITT) & & & & & & & $\begin{array}{l}-569.647 \\
{[680.474]}\end{array}$ & $\begin{array}{l}-0.123 \\
{[0.349]}\end{array}$ \\
\hline \multicolumn{9}{|l|}{ RHS variables included: } \\
\hline Randomization Phase? & yes & yes & yes & yes & yes & yes & no & no \\
\hline Surveyor fixed effects? & yes & yes & yes & yes & yes & yes & no & no \\
\hline Location fixed effects & yes & yes & yes & yes & yes & yes & no & no \\
\hline Baseline survey variables? & yes & yes & yes & yes & yes & yes & no & no \\
\hline Baseline credit score? & yes & yes & yes & yes & yes & yes & no & no \\
\hline Baseline card balances? & yes & yes & yes & yes & yes & yes & no & no \\
\hline Baseline auto balances? & yes & yes & no & yes & no & yes & no & no \\
\hline Borrower fixed effects? & no & no & no & no & no & no & yes & yes \\
\hline Observations & 234 & 234 & 234 & 234 & 234 & 234 & 702 & 702 \\
\hline R-squared/Pseudo R-squared & 0.540 & 0.291 & 0.173 & 0.624 & 0.159 & 0.475 & 0.078 & 0.142 \\
\hline
\end{tabular}

Standard errors in brackets: Huber-White for OLS (intention-to-treat) specifications, bootstrapped with 100 replications for median regression specifications, and clustered on panelist for borrower fixed effect specifications. The baseline survey and credit report variables used here are the same as used in Tables $3 a$ and $3 b .{ }^{*} p<0.10 * * p<0.05 * \star *<0.01$. 
Table 5a. BoLT Treatment Effects on Credit Scores

(1)

Dependent Variable:

Control Group Mean:

Any Treatment (OLS ITT)

Any Treatment (Borrower Fixed Effects ITT)

(2)

(3)

12-month leve

12-month change Averad from baseline

618.395

$-7.082$

[5.266]

9.112

$-5.188$

[5.665]

65]

(1)

,

614.876

$-0.811$

[4.570]

(6-month

(4)

(6)

Average change Level: baseline, 6from baselne month, 12-month

$\begin{array}{cc}5.867 \\ 0.935 \\ 0] & {[4.900]}\end{array}$

RHS variables included:

Randomization Phase?

Surveyor fixed effects?

Location fixed effects

Baseline survey variables?

Baseline credit score?

Baseline card balances?

Baseline auto balances?

Borrower fixed effects?

Observations

R-squared/Pseudo R-squared

Standard errors in brackets: Huber-White for OLS (intention-to-treat) specifications, and clustered on panelist for borrower fixed effect specifications. The baseline survey and credit report variables used here are the same as used in Tables $3 \mathrm{a}$ and $3 \mathrm{~b}$. Sample size differs slightly from other tables because individuals may not have credit scores for all credit report pulls at baseline, six months, and one year. ${ }^{*} p<0.10 * * p<0.05 * * x<0.01$.

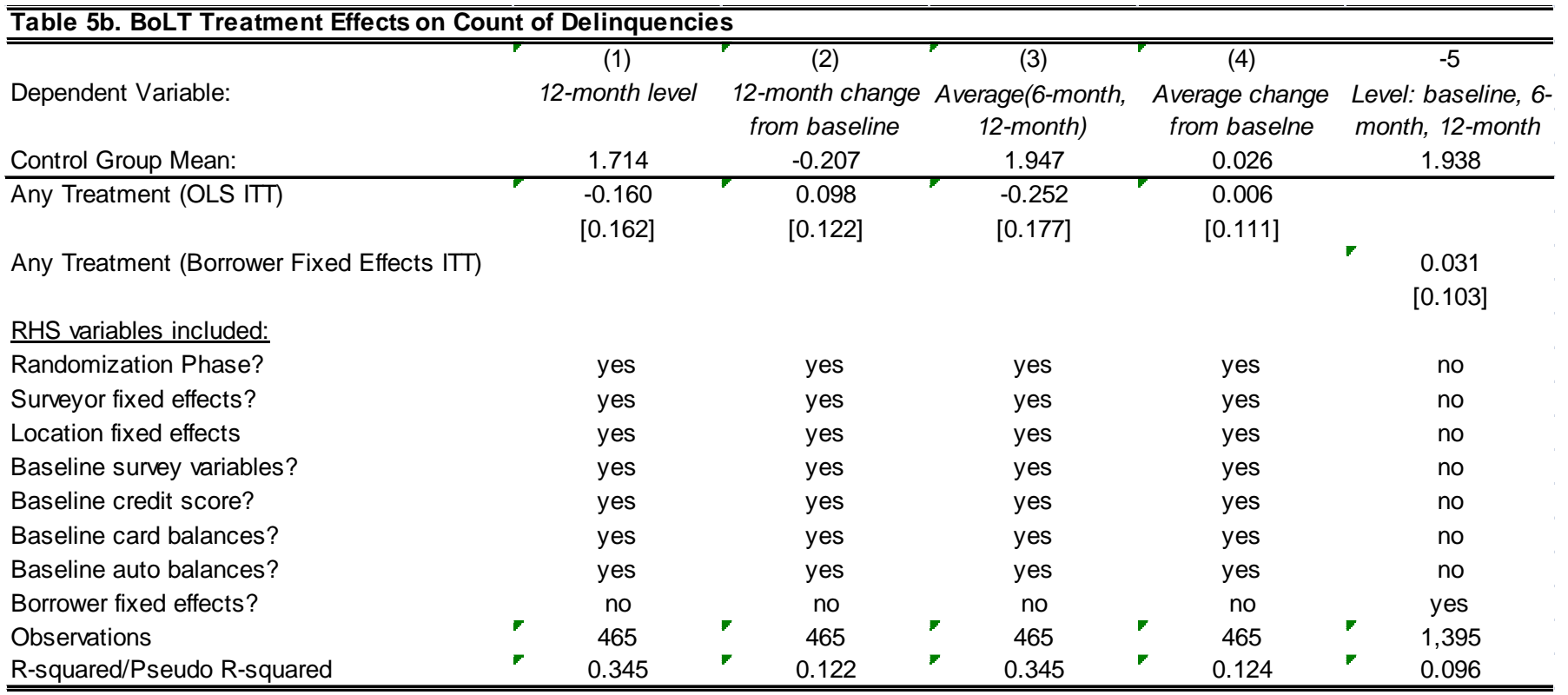

Standard errors in brackets: Huber-White for OLS (intention-to-treat) specifications, and clustered on panelist for borrower fixed effect specifications. The baseline survey and credit report variables used here are the same as used in Tables $3 \mathrm{a}$ and $3 \mathrm{~b}$. Accounts are defined as delinquent if they have a positive past due balance or are marked as delinquent in the remarks for that account. ${ }^{*} p<0.10{ }^{* *} p<0.05{ }^{* *} p<0.01$. 


\begin{tabular}{|c|c|c|c|c|c|}
\hline & $(1)$ & (2) & (3) & (4) & (6) \\
\hline Dependent Variable: & 12-month level & $\begin{array}{l}\text { 12-month change } \\
\text { from baseline }\end{array}$ & $\begin{array}{c}\text { Average(6-month, } \\
\text { 12-month) }\end{array}$ & $\begin{array}{l}\text { Average change } \\
\text { from baselne }\end{array}$ & $\begin{array}{l}\text { Level: baseline, 6- } \\
\text { month, 12-month }\end{array}$ \\
\hline Control Group Mean: & 5.211 & 0.273 & 5.947 & -0.463 & 5.793 \\
\hline Any Treatment (OLS ITT) & 0.018 & -0.116 & -0.006 & -0.092 & \\
\hline Any Treatment (Borrower Fixed Effects ITT) & [0.335] & [0.143] & {$[0.373]$} & {$[0.176]$} & $\begin{array}{c}0.129 \\
{[0.161]}\end{array}$ \\
\hline \multicolumn{6}{|l|}{ RHS variables included: } \\
\hline Randomization Phase? & yes & yes & yes & yes & no \\
\hline Surveyor fixed effects? & yes & yes & yes & yes & no \\
\hline Location fixed effects & yes & yes & yes & yes & no \\
\hline Baseline survey variables? & yes & yes & yes & yes & no \\
\hline Baseline credit score? & yes & yes & yes & yes & no \\
\hline Baseline card balances? & yes & yes & yes & yes & no \\
\hline Baseline auto balances? & yes & yes & yes & yes & no \\
\hline Borrower fixed effects? & no & no & no & no & yes \\
\hline Observations & 465 & 465 & 465 & 465 & 1,395 \\
\hline R-squared/Pseudo R-squared & 0.436 & 0.134 & 0.451 & 0.158 & 0.333 \\
\hline
\end{tabular}

Standard errors in brackets: Huber-White for OLS (intention-to-treat) specifications, and clustered on panelist for borrower fixed effect specifications. Trade lines are defined as the number of accounts appearing on an individual's credit report. If an account is marked closed in the accompanying remarks, then this account is not counted as a trade line unless it has a positive past due balance. The baseline survey and credit report variables used here are the same as used in Tables $3 a$ and $3 b .{ }^{*} p<0.10{ }^{* \star} p<0.05 * * p<0.01$.

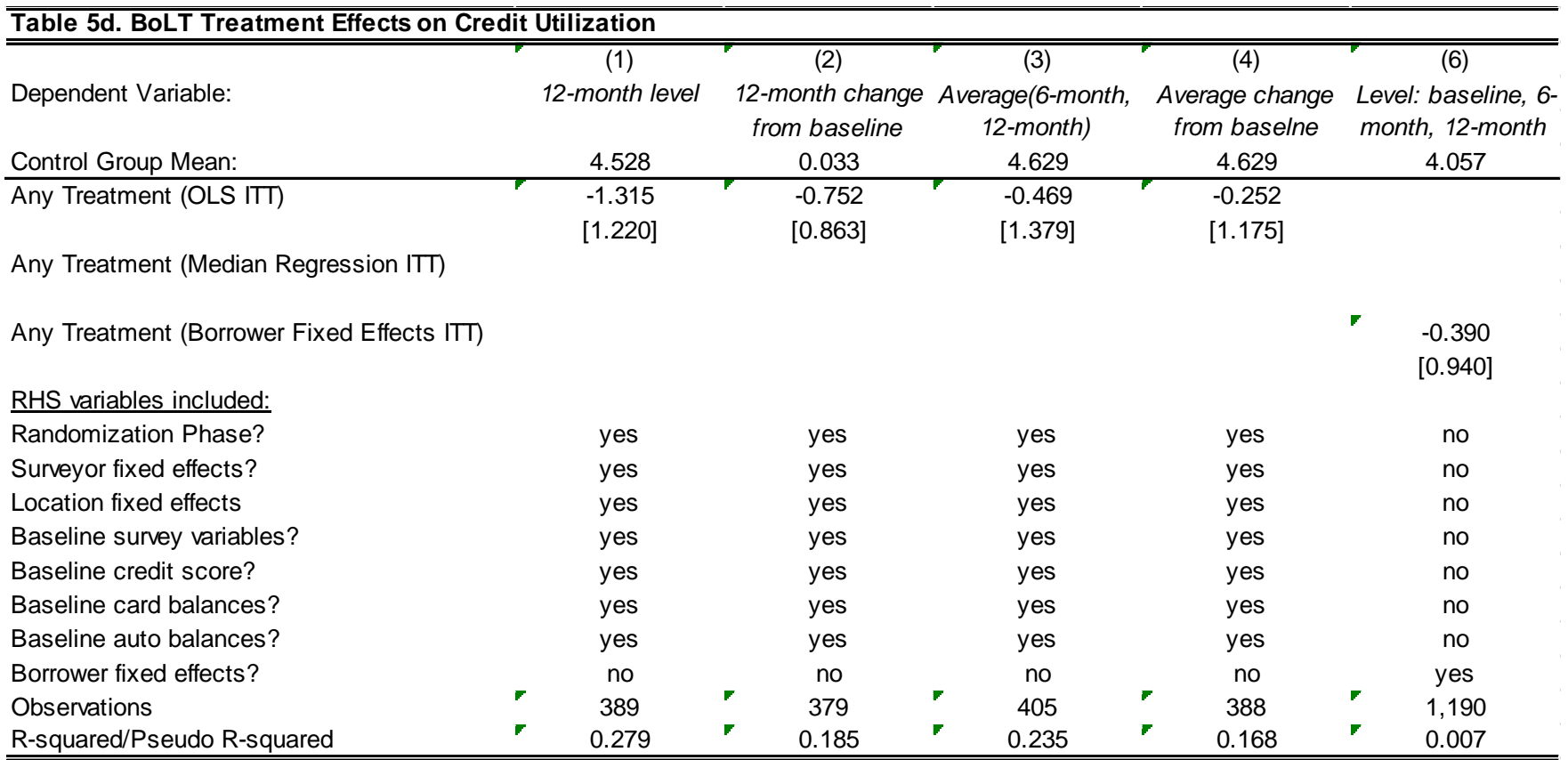

Standard errors in brackets: Huber-White for OLS (intention-to-treat) specifications, and clustered on panelist for borrower fixed effect specifications. The baseline survey and credit report variables used here are the same as used in Tables $3 a$ and $3 b$. Credit utilization is defined as the sum of balances on all accounts divided by the sum of credit limits on all accounts. Individuals may carry zero balances or have zero credit limits, resulting in lower sample size for credit utilization regressions. ${ }^{*} p<0.10 * * p<0.05{ }^{* * *} p<0.01$. 


\begin{tabular}{lccc}
\hline Appendix A: Financial Products Held at Time of Survey & & & \\
\hline & Control & $\begin{array}{c}\text { Treatment = } \\
\text { offered BoLT }\end{array}$ & $\begin{array}{c}\text { Difference } \\
\text { (p-value) }\end{array}$ \\
\hline Financial Products Held at Time of Survey (dummies): & & & \\
Checking Account & $84 \%$ & $87 \%$ & 0.48 \\
Savings Account & $56 \%$ & $57 \%$ & 0.99 \\
CD/Investment Account & $28 \%$ & $27 \%$ & 0.49 \\
Credit Card & $45 \%$ & $55 \%$ & 0.13 \\
Refund Anticipation Loan & $2 \%$ & $4 \%$ & $0.05^{\star \star}$ \\
Payday Loan & $8 \%$ & $15 \%$ & $0.02^{\star \star}$ \\
Auto Loan & $47 \%$ & $50 \%$ & 0.91 \\
Auto Title Loan & $14 \%$ & $18 \%$ & 0.24 \\
Negative Checking Balance / Overdraft & $15 \%$ & $15 \%$ & 0.88 \\
Rent-to-own & $4 \%$ & $5 \%$ & 0.96 \\
Pawn Loan & $7 \%$ & $9 \%$ & 0.33 \\
Home Mortgage & $34 \%$ & $28 \%$ & $0.09^{\star}$ \\
& & & \\
\hline
\end{tabular}




\section{References}

Angeletos, George-Marios, David Laibson, Jeremy Tobacman, Andrea Repetto, and Stephen Weinberg. 2001. "The Hyperbolic Consumption Model: Calibration, Simulation, and Empirical Evaluation.” Journal of Economic Perspectives 15 (3): 47-68.

Ashraf, N., D. Karlan, and W. Yin. 2006. "Tying Odysseus to the Mast: Evidence from a Commitment Savings Product in the Philippines.” Quarterly Journal of Economics 121 (2) (May): 635-672.

Benartzi, Shlomo, and Richard Thaler. 2004. "Save More Tomorrow: Using Behavioral Economics to Increase Employee Saving.” Journal of Political Economy 112 (1, Part 2 Supplement): S164S187.

Bergstresser, Daniel, John Chalmers, and Peter Tufano. “Assessing the Costs and Benefits of Brokers in the Mutual Fund Industry.” Review of Financial Studies 22 (10): 4129-4156.

Berndt, Antje, Burton Hollifield, and Patrik Sandas. 2010. "The Role of Mortgage Brokers in the Subprime Crisis.” NBER Working Paper No. 16175 (July).

Bertrand, Marianne, Dean Karlan, Sendhil Mullainathan, Eldar Shafir, and Jonathan Zinman. 2010. "What's Advertising Content Worth? Evidence from a Consumer Credit Marketing Field Experiment.” Quarterly Journal of Economics 125 (1) (February): 263-305.

Beshears, John, James Choi, David Laibson, Brigette Madrian, and Katherine Milkman. 2011. "The Effect of Providing Peer Information on Retirement Savings Decisions.” NBER Working Paper No. 17345 (August).

Brown, Alexander L., Zhikang Eric Chua, and Colin Camerer. 2009. "Learning and Visceral Temptation in Dynamic Savings Experiments.” The Quarterly Journal of Economics 124 (1) (February): 197-230.

Brown, Meta, Andrew Haughwout, Donghoon Lee, and Wilbert van der Klaauw. 2011. “Do We Know What We Owe? A Comparison of Borrower- and Lender-reported Debt.” Federal Reserve Bank of New York Staff Report (523).

Choi, James, Gabriel Carroll, David Laibson, Brigitte C Madrian, and Andrew Metrick. 2009. “Optimal Defaults and Active Decisions.” The Quarterly Journal of Economics 124 (4) (November): 1639-1674.

Choi, James, Emily Haisely, Jennifer Krukoski, and Cade Massey. 2011. "Small Cues Change Savings Choices.”

Cialdini, Robert, and Noah Goldstein. 2004. “Social Influence: Compliance and Conformity.” Annual Review of Psychology 55: 591-621. 
Collins, J. Michael, and Collin O’Rourke. 2010. "Financial Education and Counseling-- Still Holding Promise.” Journal of Consumer Affairs 44 (3): 483-498.

DellaVigna, Stefano. 2009. "Psychology and Economics: Evidence from the Field.” Journal of Economic Literature 47 (2) (June): 315-372.

Duflo, Esther, William Gale, Jeffrey Liebman, Peter Orszag, and Emmanuel Saez. 2006. "Saving Incentives for Low- and Middle-Income Families: Evidence from a Field Experiment with H\&R Block.” Quarterly Journal of Economics 121 (4): 1311-1346.

Gerardi, Kristopher, Lorenz Goette, and Stephan Meier. 2010. "Financial Literacy and Subprime Mortgage Delinquency: Evidence from a Survey Matched to Administrative Data.” Federal Reserve Bank of Atlanta Working Paper Series No. 2010-10 (April).

Gine, Xavier, Dean Karlan, and Jonathan Zinman. 2010. "Put Your Money Where Your Butt Is: A Commitment Contraction for Smoking Cessation.” American Economic Journal: Applied Economics 2 (4) (October): 213-35.

Hackethal, Andreas, Michael Haliassos, and Tullio Jappelli. 2012. "Financial Advisors: A Case of Babysiters?” Journal of Banking \& Finance 36 (2) (February): 509-524.

Iyengar, Sheena, Gur Huberman, and Wei Jiang. 2004. "How Much Choice Is Too Much? Contributions to 401(k) Retirement Plans.” In Pension Design and Structure: New Lessons from Behavioral Finance, ed. O. Mitchell and S. Utkus, 83-95. Oxford: Oxford University Press.

Karlan, Dean, Margaret McConnell, Sendhil Mullainathan, and Jonathan Zinman. 2011. "Getting to the Top of Mind: How Reminders Increase Saving”. Working Paper.

Karlan, Dean, and Jonathan Zinman. 2008. “Lying About Borrowing.” Journal of the European Economic Association Papers and Proceedings 6 (2-3) (August).

Kast, Felipe, Stephan Meier, and Dina Pomeranz. 2012. "Under-Savers Anonymous: Evidence on Selfhelp Groups and Peer Pressure as a Savings Commitment Device.”

Lusardi, Annamaria, and Peter Tufano. 2009. "Debt Literacy, Financial Experience, and Overindebtedness.” NBER Working Paper No. 14808 (March).

Madrian, B., and D. Shea. 2001. "The Power of Suggestion: Inertia in 401(k) Participation and Savings Behavior.” Quarterly Journal of Economics 116 (4): 1149-1188.

Meier, Stephan, and Charles Sprenger. 2010. "Present-biased Preferences and Credit Card Borrowing." American Economic Journal: Applied Economics 2 (1): 193-210.

Mullainathan, Sendhil, Markus Noth, and Antoinette Schoar. 2011. "The Market for Financial Advice: An Audit Study.” 
Peetz, Joanna, and Roger Buehler. 2009. "Is There a Budget Fallacy? The Role of Savings Goals in the Prediction of Personal Spending.” Personality and Social Psychology Bulletin 35 (12)

(December): 1579-1591.

Scholz, J.K., A. Seshadri, and S. Khitatrakun. 2006. “Are Americans Saving 'Optimally’ for Retirement?” Journal of Political Economy 114 (4) (August): 607-643.

Skinner, Jonathan. 2007. “Are You Sure You’re Saving Enough for Retirement?” Journal of Economic Perspectives 21 (3): 59-80.

Soll, Jack B., Ralph L. Keeney, and Richard P. Larrick. 2011. "Consumer Misunderstanding of Credit Card Use, Payments, and Debt: Causes and Solutions.”

Stango, Victor, and Jonathan Zinman. 2009. “Exponential Growth Bias and Household Finance.” Journal of Finance 64 (6): 2807-2849.

—. 2011a. "Limited and Varying Consumer Attention: Evidence from Shocks to the Salience of Bank Overdraft Fees.”

—. 2011b. "Fuzzy Math, Disclosure Regulation, and Credit Market Outcomes: Evidence from Truth-in-Lending Reform.” Review of Financial Studies 24 (2): 506-534.

Wilshusen, Stephanie. 2011. “Meetng the Demand for Debt Relief.” Federal Reserve Bank of Philadephia Payment Cards Center DP11-04 (August).

Woodward, Susan E., and Robert E Hall. "Diagnosing Consumer Confusion and Sub-Optimal Shopping E_Ort: Theory and Mortgage-Market Evidence.” American Economic Review.

Zinman, Jonathan. 2009. "Where Is the Missing Credit Card Debt? Clues and Implications.” Review of Income and Wealth 55 (2): 249-265.

- 2010. "Restricting Consumer Credit Access: Household Survey Evidence on Effects Around the Oregon Rate Cap.” Journal of Banking \& Finance 34 (3) (March): 546-556. 


\section{Appendix 1. Baseline Survey}

1. Sex $\square$ Male $\square$ Female $\quad \square$ Don’t know $\quad \square$ Refused

2. First Name

Refused

3. Last Name

Don’t know

Refused

4. What is the best phone number to reach you?

$\square$ Cell $\square$ House $\square$ Work

$\square$ Don’t know $\square$ Refused

5. Current mailing address: $\quad \square$ Don't know $\quad \square$ Refused

Street

City

Zip Code

6. Do you live at this address?

$\underset{\text { Don't know }}{\square \text { Yes ( } \rightarrow \text { Skip to 8) }} \underset{\square \text { Refused }}{\square \text { No }}$

7. What is the address where you currently live? $\quad \square$ Don’t know $\quad \square$ Refused Street

City

Zip Code

8. What is your date of birth?

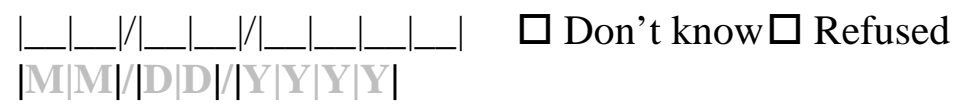

9. What was your annual household income in 2009? Was it less than 10 thousand, 10 to 20 thousand, 20 to 30 thousand, 30 to 40 thousand, 40 to 50 thousand, or more than 50 thousand?
$\square<\$ 10,000$
$\square \$ 30-40,000$
Don't know
$\$ 10-20,000$
$\$ 40-50,000$
Refused
$\$ 20-30,000$
$\square>\$ 50,000$

10. What is the highest level of school you've attained?
$\square$ Less than $9^{\text {th }}$ grade
$\square$ Some college
Some High School
Associate's Degree
Doctorate Degree
$\square$ Don’t know 
$\begin{array}{lll}\square \text { High School Graduate } & \square \text { Bachelor's Degree } & \square \text { Refused } \\ \square \text { GED } & \square \text { Master’s Degree } & \\ \square & \text { Trade School } & \square \text { Professional Degree }\end{array}$

11. How much have you thought about what your financial situation will be like over the next year? Would you say "a lot," "somewhat," or "hardly at all”?
$\square$ A lot
$\square$ Don't know
Somewhat
$\square$ Refused
$\square$ Hardly at all

12. How would you describe your overall financial situation? Would you say "excellent," "very good," "ok," "not very good," or "bad"?
Excellent
Not very good
Don’t know
Very good
Bad
$\square$ Refused

Good

13. Have you recently been turned down for credit or not received as much credit as you applied for?
$\square$ Yes
Don't know
$\square$ No
Refused

14. Was there any time in the past few years that you thought about applying for credit but you decided not to because you thought you would be turned down?
$\square$ Yes
$\square$ Don't know
$\square$ No
$\square$ Refused

15. During the last 12 months, was there a time when you and your family were not able to pay your rent mortgage or utilities bills?
$\square$ Yes
$\square$ Don't know
No
$\square$ Refused

16. During the last 12 months, have you or anyone in your household moved in with other people ever for a little while because you could not afford to pay your mortgage, rent or utilities bills?
$\square$ Yes
Don't know
No
$\square$ Refused

17. In the last 12 months, did you or other adults in your family ever cut the size of your meals or skip meals because there wasn't enough money for food?
$\square$ Yes
Don't know
No
$\square$ Refused

18. Please choose how much you agree or disagree with the following statement: "I often find that I regret spending money. I wish that when I had cash, I was better disciplined and saved 
my money rather than spent it.” Do you strongly agree, somewhat agree, somewhat disagree, or strongly disagree?
$\square$ Strongly agree
$\square$ Don't know
Somewhat agree
$\square$ Refused
Somewhat disagree
Strongly disagree

19. Supposed the town of Greenville currently has a population of 1,000. Each year, the population gets $7 \%$ biggers. After ten years, about what will the population of Greenville be?

$$
\square \text { Don’t know } \quad \square \text { Refused }
$$

20. Suppose the Community Action Project held a raffle and you won. You have a choice: you can collect \$65 in cash today, or \$80 in cash one month from today. Which would you choose?

$\$ 65$ today $(\rightarrow$ Read $A)$

\section{Don't know}

$\square$ \$80 in one month $\quad$ ( $\rightarrow$ Skip to 21$) \quad \square$ Refused

A. How much would the cash prize have to be for you to choose to wait a month instead of collecting the $\$ 65$ cash today?
$\$$
$\square$ Don’t know
Refused

21. Now let's say the choice is between collecting a $\$ 65$ cash prize 6 months from today or an $\$ 80$ cash prize 7 months from today. Which would you choose?

$\$ 65$ six months from today $(\rightarrow \operatorname{Read} A)$

$\$ 80$ seven months from today ( $\rightarrow$ Skip to 21 )

\author{
$\square$ Don’t know \\ Refused
}

A. How much would the cash prize have to be for you to choose to wait a month instead of collecting the $\$ 65$ cash today?

\$— $\square$ Don’t know $\square$ Refused

22. Now I'm going to ask you about a number of financial products.

a. Do you currently have a ...... ?
i. Checking account $\square \mathrm{Y} \square \mathrm{N}$
ii. Savings account $\square \mathrm{Y} \square \mathrm{N}$
iii. $\underline{\text { CD or investment account }}$ $\square \mathrm{Y} \square \mathrm{N}$
iv. $\underline{\text { Credit card }}$ $\square \mathrm{Y} \square \mathrm{N}$
v. Refund anticipation loan
$\square \mathrm{Y} \square \mathrm{N}$ 


\begin{tabular}{|c|c|}
\hline vi. Payday loan & $\square \mathrm{Y} \square \mathrm{N} \square \mathrm{DK} \underline{\mathrm{R}}$ \\
\hline vii. Auto loan & $\square \mathrm{Y} \square \mathrm{N} \square \mathrm{DK} \underline{\mathrm{R}}$ \\
\hline viii. Auto title loan & $\square \mathrm{Y} \square \mathrm{N} \square \mathrm{DK} \underline{\mathrm{R}}$ \\
\hline ix. Negative balance on checking acct (overdraft) & $\square \mathrm{Y} \square \mathrm{N} \square$ \\
\hline$\underline{\mathrm{R}}$ & \\
\hline x. Rent-to-own & $\square \mathrm{Y} \square \mathrm{N} \square \mathrm{DK} \square$ \\
\hline xi. Pawn loan & $\square \mathrm{Y} \square \mathrm{N} \square \mathrm{DK} \square$ \\
\hline
\end{tabular}

xii. Home mortgage

1. On a mobile home or a house?

Mobile Home

$\square \mathrm{Y} \square \mathrm{N} \square \mathrm{DK} \underline{\mathrm{R}}$

House

$\square \mathrm{Y} \square \mathrm{N} \square \mathrm{DK} \underline{\mathrm{R}}$

b. In the past two years have you had a ...... ?

\begin{tabular}{|c|c|}
\hline i. Checking account & $\square \mathrm{Y} \square \mathrm{N} \square \mathrm{DK} \square \mathrm{R}$ \\
\hline ii. Savings account & $\square \mathrm{Y} \square \mathrm{N} \square \mathrm{DK} \underline{\mathrm{R}}$ \\
\hline iii. $\underline{\mathrm{CD} \text { or investment account }}$ & $\square \mathrm{Y} \square \mathrm{N} \square \mathrm{DK} \underline{\mathrm{R}}$ \\
\hline iv. $\underline{\text { Credit card }}$ & $\square \mathrm{Y} \square \mathrm{N} \square \mathrm{DK} \underline{\mathrm{P}}$ \\
\hline v. Refund anticipation loan & $\square \mathrm{Y} \square \mathrm{N} \square \mathrm{DK} \underline{\mathrm{H}}$ \\
\hline vi. Payday loan & $\square \mathrm{Y} \square \mathrm{N} \square \mathrm{DK} \underline{\mathrm{P}}$ \\
\hline vii. Auto loan & $\square \mathrm{Y} \square \mathrm{N} \square \mathrm{DK} \square$ \\
\hline viii. Auto title loan & $\square \mathrm{Y} \square \mathrm{N} \square \mathrm{DK} \square$ \\
\hline ix. Negative balance on checking acct (overdraft) & $\square \mathrm{Y} \square \mathrm{N} \square$ \\
\hline
\end{tabular}

x. Rent-to-own

$\square \mathrm{Y} \square \mathrm{N} \square \mathrm{DK} \underline{\mathrm{R}}$

xi. Pawn loan

$\square \mathrm{Y} \square \mathrm{N} \square \mathrm{DK}$ 므

xii. Home mortgage

1. On a mobile home or a house?

Mobile Home

$\square \mathrm{Y} \square \mathrm{N} \square \mathrm{DK} \underline{\mathrm{R}}$

House

$\square \mathrm{Y} \square \mathrm{N} \square \mathrm{DK} \underline{\mathrm{R}}$ 
23. Suppose Bob takes a loan of $\$ 1,000$ to pay for college tuition at an interest rate of $7 \%$ per year. If Bob doesn't make any payment on this loan, then how much in total will he owe after ten years? Please give your best guess:

$\$$

$\square$ Don’t know $\quad \square$ Refused 


\section{Appendix 2. Decision Aid}

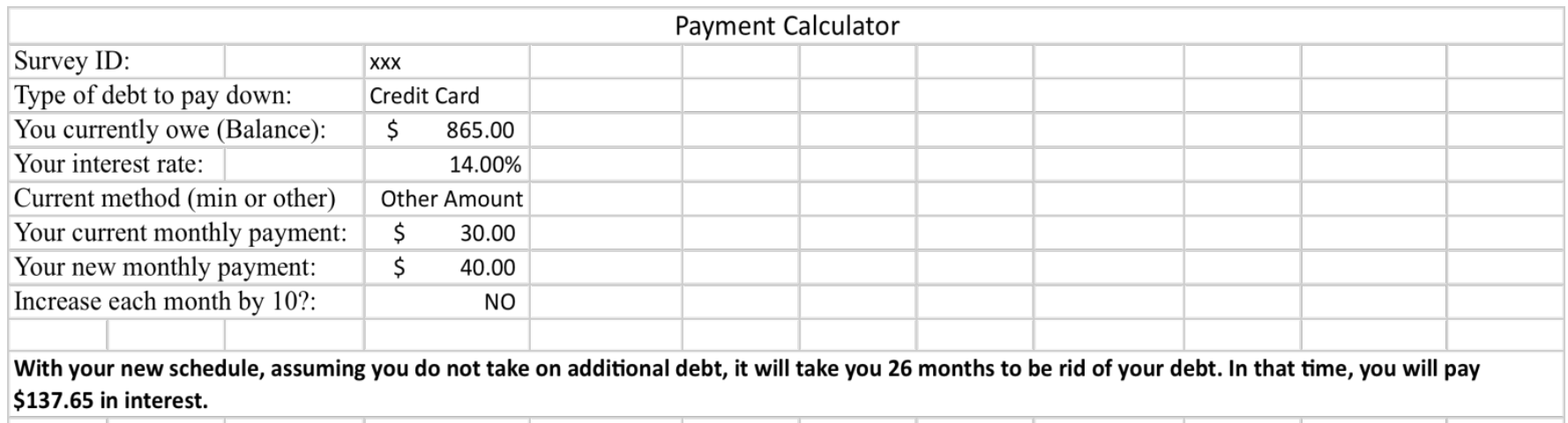

With your current schedule, assuming you do not take on additional debt, it would take you $\mathbf{3 6}$ months, to pay off your debit and you would pay \$195.62 in interest.

Thus, by paying 40 per month you will be out of debt 10 months faster and will save $\$ 57.97$ in interest

\begin{tabular}{|c|c|c|c|c|c|c|c|c|c|c|}
\hline \\
\hline & & & & & & & & & & \\
\hline \multicolumn{5}{|c|}{ Your New Payment Schedule } & \multicolumn{5}{|c|}{ Your Current Payment Schedule } & \\
\hline Month & Payment & Interest Paid & Principal Paid & $\begin{array}{c}\text { Remaining } \\
\text { Balance }\end{array}$ & Month & Payment & Interest Paid & $\begin{array}{c}\text { Principal } \\
\text { Paid } \\
\end{array}$ & $\begin{array}{c}\text { Remaining } \\
\text { Balance }\end{array}$ & \\
\hline 1 & 40.00 & 10.09 & 29.91 & 835.09 & 1 & 30.00 & 10.09 & 19.91 & 845.09 & \\
\hline 2 & 40.00 & 9.74 & 30.26 & 804.83 & 2 & 30.00 & 9.86 & 20.14 & 824.95 & \\
\hline 3 & 40.00 & 9.39 & 30.61 & 774.22 & 3 & 30.00 & 9.62 & 20.38 & 804.58 & \\
\hline 4 & 40.00 & 9.03 & 30.97 & 743.26 & 4 & 30.00 & 9.39 & 20.61 & 783.96 & \\
\hline 5 & 40.00 & 8.67 & 31.33 & 711.93 & 5 & 30.00 & 9.15 & 20.85 & 763.11 & \\
\hline 6 & 40.00 & 8.31 & 31.69 & 680.23 & 6 & 30.00 & 8.90 & 21.10 & 742.01 & \\
\hline 7 & 40.00 & 7.94 & 32.06 & 648.17 & 7 & 30.00 & 8.66 & 21.34 & 720.67 & \\
\hline 8 & 40.00 & 7.56 & 32.44 & 615.73 & 8 & 30.00 & 8.41 & 21.59 & 699.08 & \\
\hline 9 & 40.00 & 7.18 & 32.82 & 582.92 & 9 & 30.00 & 8.16 & 21.84 & 677.23 & \\
\hline 10 & 40.00 & 6.80 & 33.20 & 549.72 & 10 & 30.00 & 7.90 & 22.10 & 655.13 & \\
\hline 11 & 40.00 & 6.41 & 33.59 & 516.13 & 11 & 30.00 & 7.64 & 22.36 & 632.78 & \\
\hline 12 & 40.00 & 6.02 & 33.98 & 482.15 & 12 & 30.00 & 7.38 & 22.62 & 610.16 & \\
\hline 13 & 40.00 & 5.63 & 34.37 & 447.78 & 13 & 30.00 & 7.12 & 22.88 & 587.28 & \\
\hline 14 & 40.00 & 5.22 & 34.78 & 413.00 & 14 & 30.00 & 6.85 & 23.15 & 564.13 & \\
\hline 15 & 40.00 & 4.82 & 35.18 & 377.82 & 15 & 30.00 & 6.58 & 23.42 & 540.71 & \\
\hline 16 & 40.00 & 4.41 & 35.59 & 342.23 & 16 & 30.00 & 6.31 & 23.69 & 517.02 & \\
\hline 17 & 40.00 & 3.99 & 36.01 & 306.22 & 17 & 30.00 & 6.03 & 23.97 & 493.05 & \\
\hline 18 & 40.00 & 3.57 & 36.43 & 269.79 & 18 & 30.00 & 5.75 & 24.25 & 468.80 & \\
\hline 19 & 40.00 & 3.15 & 36.85 & 232.94 & 19 & 30.00 & 5.47 & 24.53 & 444.27 & \\
\hline 20 & 40.00 & 2.72 & 37.28 & 195.66 & 20 & 30.00 & 5.18 & 24.82 & 419.46 & \\
\hline 21 & 40.00 & 2.28 & 37.72 & 157.94 & 21 & 30.00 & 4.89 & 25.11 & 394.35 & \\
\hline 22 & 40.00 & 1.84 & 38.16 & 119.78 & 22 & 30.00 & 4.60 & 25.40 & 368.95 & \\
\hline 23 & 40.00 & 1.40 & 38.60 & 81.18 & 23 & 30.00 & 4.30 & 25.70 & 343.25 & \\
\hline 24 & 40.00 & 0.95 & 39.05 & 42.13 & 24 & 30.00 & 4.00 & 26.00 & 317.26 & \\
\hline 25 & 40.00 & 0.49 & 39.51 & 2.62 & 25 & 30.00 & 3.70 & 26.30 & 290.96 & \\
\hline \multirow[t]{11}{*}{26} & 2.65 & 0.03 & 2.62 & 0.00 & 26 & 30.00 & 3.39 & 26.61 & 264.35 & \\
\hline & & & & & 27 & 30.00 & 3.08 & 26.92 & 237.44 & \\
\hline & & & & & 28 & 30.00 & 2.77 & 27.23 & 210.21 & \\
\hline & & & & & 29 & 30.00 & 2.45 & 27.55 & 182.66 & \\
\hline & & & & & 30 & 30.00 & 2.13 & 27.87 & 154.79 & \\
\hline & & & & & 31 & 30.00 & 1.81 & 28.19 & 126.60 & \\
\hline & & & & & 32 & 30.00 & 1.48 & 28.52 & 98.07 & \\
\hline & & & & & 33 & 30.00 & 1.14 & 28.86 & 69.22 & \\
\hline & & & & & 34 & 30.00 & 0.81 & 29.19 & 40.03 & \\
\hline & & & & & 35 & 30.00 & 0.47 & 29.53 & 10.49 & \\
\hline & & & & & 36 & 10.62 & 0.12 & 10.49 & 0.00 & \\
\hline
\end{tabular}


Date:

To: (name) (address)

I have just signed up for an innovative new program to help me get out of debt. The program is called "Borrow Less Tomorrow" (BoLT) and is offered by Innovations for Poverty Action (IPA), in partnership with the Community Action Project of Tulsa County (CAPTC).

As part of the program I have created a repayment schedule to help pay off one of my high interest debts. To help my stick to my plan IPA and CAPTC gave me the option of naming peers to support and encourage me. IPA will monitor my progress over the next year and if they notice that I fall off track from my repayment plan, they will inform my peer supporters and ask that they get in touch with me to encourage me get back on track.

I have enlisted you to be one of my peer supporters in helping me stick to my debt repayment plan. If I have trouble following my repayment schedule, IPA will let you know and ask that you help encourage me to stick to it. You are not being asked in any form to help contribute to my payments or back my payments if I cannot make them. I hope you will support me in this endeavor to escape from debt.

Thank you for your support,

(write name)

(signature)

If you do not know or do not wish to be a peer supporter for this individual, or if you wish to update your contact information for IPA to contact you, please contact:

Senior Project Associate

Innovations for Poverty Action

@poverty-action.org 


\section{Appendix 3b. Peer Supporter Contact Script}

Hello. My name is I work for Innovations for Poverty Action, a non-profit organization that does research to help people achieve their financial goals. We are not a debt collection agency. We are calling because your friend identified you as someone who can help encourage him/her to maintain financial commitments. Your friend has recently agreed to a payment schedule to pay down his loans faster. If your friend happens to fall behind schedule, we would like you to contact him/her to give him/her support and encouragement to get back on track.

Are you willing to contact and give him/her the encouragement he/she needs to maintain her commitment? We will only ask you to contact them if they actually do fall behind on their schedule. 


\section{Appendix 3c. Reminder to Client Script}

\section{PHONE:}

Dear Mr/Mrs.,

My name is __. I work at Innovations for Poverty Action, a nonprofit charity. On [Day] [Month] - [Year], you made a commitment to pay down your CREDIT CARD / AUTO LOAN faster and save money in interest. I was calling to remind you about your commitment, which goes into effect this month. According to the new payment schedule you agreed to, you should be paying \$[CHECK AMOUNT] on this loan in the month of __. I was calling simply to remind you about your commitment and encourage you to stick to it. Keeping up with your payments will save you money and get you out of debt quicker.

Thank you and have a nice day.

Regards,

\section{EMAIL:}

Dear Mr/Mrs.,

My name is I work at Innovations for Poverty Action, a nonprofit charity. This message is to remind you about the commitment you made on [Day] - [Month] - [Year] to increase your monthly CREDIT CARD / AUTO LOAN payments. According to the payment schedule you committed to, you should be paying \$[CHECK AMOUNT] on this loan in the month of ___ This message is simply to remind you of your commitment and encourage you to stick to it. Keeping up with the schedule will save you money and get you out of debt faster.

Please keep in mind that Innovations for Poverty Action is a nonprofit charity. We are not a debt collection agency, nor have we ever been affiliated with one. We conduct research aimed at helping ordinary people build healthier financial lives. Feel free to visit our website at www.povertyaction.org for more information about or organization.

Regards,

Innovations for Poverty Action 